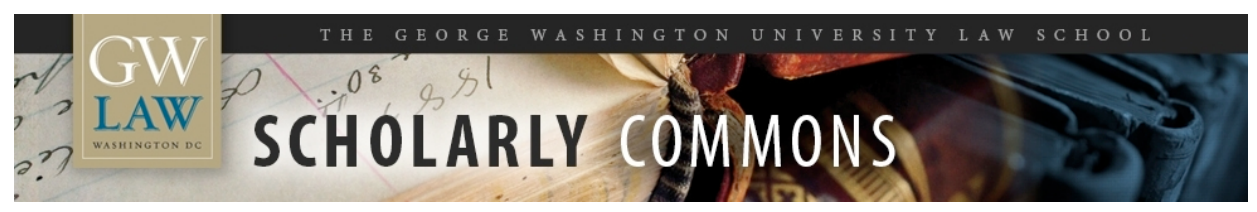

\title{
Train Wrecks, Budget Deficits, and the Entitlements Explosion: Exploring the Implications of the Fourteenth Amendment's Public Debt Clause
}

Michael B. Abramowicz

George Washington University Law School, abramowicz@law.gwu.edu

Follow this and additional works at: https://scholarship.law.gwu.edu/faculty_publications

Part of the Law Commons

\section{Recommended Citation}

Abramowicz, Michael B., "Train Wrecks, Budget Deficits, and the Entitlements Explosion: Exploring the Implications of the Fourteenth Amendment's Public Debt Clause" (2011). GW Law Faculty Publications \& Other Works. 193.

https://scholarship.law.gwu.edu/faculty_publications/193

This Article is brought to you for free and open access by the Faculty Scholarship at Scholarly Commons. It has been accepted for inclusion in GW Law Faculty Publications \& Other Works by an authorized administrator of Scholarly Commons. For more information, please contact spagel@law.gwu.edu. 


\title{
Train Wrecks, Budget Deficits, and the Entitlements Explosion: Exploring the Implications of the Fourteenth Amendment's Public Debt Clause
}

\author{
Michael Abramowicz
}

\section{CONTENTS}

I. The Continuing Vitality of The Public DeBt Clause..........6

A. The History of the Public Debt Clause...................................6 6

1. Evolution of the Clause in Congress ................................... 7

2. The Political and Economic Context of the Framing ..........10

B. Jurisprudence on the Public Debt Clause .................................. 13

1. Perry v. United States........................................................13

2. Perry's Jurisprudential Vitality ......................................... 14

C. Interpreting the Public Debt Clause Today ............................... 15

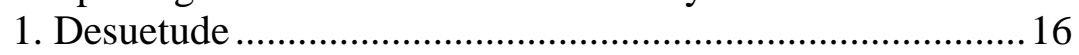

2. Normative Arguments .................................................. 17

II. The MEAning Of THE PubliC DeBt Clause ............................ 18

A. Obligations Included Within the Public Debt ...........................19

B. Congressional Actions Triggering the Clause ..........................21

1. Possible Levels of Generality ...........................................22

2. Linguistic Evidence......................................................... 24

a. Meaning of “to Question” .....................................24

b. Passive Construction ..............................................25

c. The Word "Validity" .............................................25

d. Evolution of the Language .....................................27

3. Historical Evidence ........................................................2 27

4. Identifying Debt Questionings ..........................................28

C. Outer Reaches of the Clause's Meaning................................... 31

III. APPLiCATIONS OF THE PUBLIC DEBT CLAUSE ..............................32

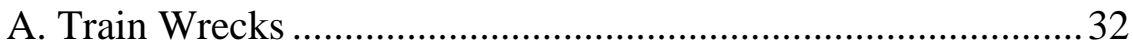

1. Governmental Failure to Make Payments on Bonds............34

2. Non-Bond Obligations Within the Public Debt ................... 35

3. The Federal Debt-Limit Statute........................................... 36 


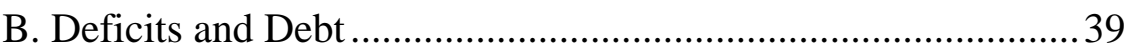

1. Unsustainable Debt Accumulation..........................................39

2. Legislation Forcing Deficit Reduction...................................41

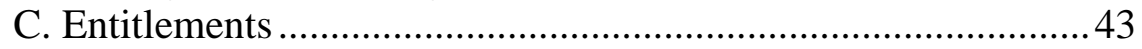

IV. JUSTICIABILITY OF THE PUBLIC DeBT CLAUSE ...............................45

A. Sovereign Immunity .............................................................46

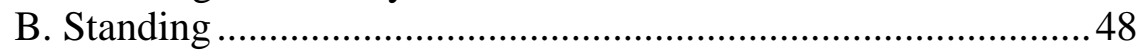

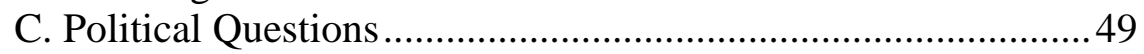

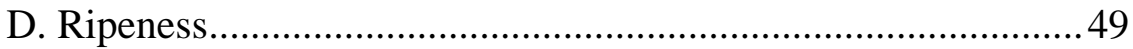

E. Separation of Powers .................................................................49

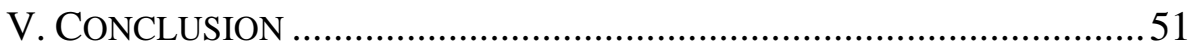


The validity of the public debt of the United States, authorized by law, including debts incurred for payment of pensions and bounties for services in suppressing insurrection or rebellion, shall not be questioned. ... ${ }^{1}$

Milling among the tourists and homeless in Lafayette Park across from the White House in the mid-1980s was a protester carrying a sign with a unique political message: "Arrest Me. I Question the Validity of the Public Debt. Repeal Section 4, Fourteenth Amendment to the U.S. Constitution.”2 Although we can safely dismiss the protester's tongue-in-cheek concern that $\S 4$ overrides the First Amendment, the mock protest makes two points worth noting. First, the wording of the first sentence of $\S 4$ is open to a wide range of interpretation. And second, the section has become obscure, less likely to be cited in policy discussion ${ }^{3}$ than in a Washington joke.

"The validity of the public debt ... shall not be questioned." This Article argues that these words mean that the government must be able to meet its fiscal commitments and applies this interpretation to assorted aspects of congressional fiscal management. After all, some might say that since the 1980s, the congressional budget process itself has become a Washington joke. Congress and the President compete over budget policy in a high-stakes game of fiscal chicken. ${ }^{4}$ Deficits add to an accumulating debt ${ }^{5}$ that is sure to escalate beyond the time horizons of balanced-budget plans. ${ }^{6}$ And politicians agree only on the sanctity of entitlement spending, ${ }^{7}$ even as

\footnotetext{
${ }^{1}$ U.S. CONST. amend. XIV, § 4. Section 4 continues:

But neither the United States nor any State shall assume or pay any debt or obligation incurred in aid of insurrection or rebellion against the United States, or any claim for the loss or emancipation of any slave; but all such debts, obligations and claims shall be held illegal and void.

${ }^{2}$ See Irvin Molotsky, Lafayette Park: Not Just Another Pretty Postcard, N.Y. Times, Sept. 7, 1984, at A13.

${ }^{3}$ Indeed, the protester's cryptic reference is the only citation of Section 4 in LEXIS/NEXIS's New York Times database.

${ }^{4}$ See Stephen Barr \& Michael A. Fletcher, Government Shuts Again After Talks Collapse, WAsh. Post, Dec. 16, 1995, at A1; Jackie Calmes \& David Rogers, Federal Offices Are Preparing for Shutdown, WALL ST. J., Nov. 10, 1995, at A2 (anticipating possibility of government shutdown and bond default). At the end of the latest impasse, Congress blinked. By then, the government had shut down twice, but avoided default on its bonds. See Monica Borkowski, The Budget Truce: Status Report, N.Y. Times, Apr. 26, 1996, at A22; Christopher Georges, Congress Passes Debt-Ceiling Measure, Agrees to Spend More on Social Security, WALL ST. J., Mar. 29, 1996, at A12.

${ }^{5}$ The 1996 budget deficit has been projected at \$144 billion. See Congressional BudgET OfFice, The ECONOMIC AND Budget OutLOOK: FiscAL YeARs 1997-2006 at xviii (1996).

${ }^{6}$ Both the President and Congress have unveiled plans that they claim would balance the budget by 2002. The Congressional Budget Office projects, however, that deficits will climb after 2002, especially beginning in about 2010 with the retirement of the baby-boom generation. See id. at xxv.

${ }^{7}$ See, e.g., Robert Bixby, The Missing Debate: Hard Choices on Entitlements, ST.
} 
economists warn that the United States of the twenty-first century will be unable to deliver on its twentieth century promises. ${ }^{8}$

In short, the budget process needs mending. ${ }^{9}$ But in none of these areas does reform of congressional practice require a constitutional amendment $^{10}$ or a sudden congressional commitment to fiscal soundness. Rather, reform can evolve from the first sentence of $\S 4$, the Constitution's Public Debt Clause. ${ }^{11}$ More prominent provisions of the Fourteenth Amendment have long overshadowed the Clause, ${ }^{12}$ assumed to be an anachronism $^{13}$ from a war whose fiscal rifts healed faster than its emotional

Petersburg Times, Oct. 6, 1996, at 1D.

${ }^{8}$ See, e.g., CONGRESSIONAL BudGET OfFICE, supra note 5, at xxiii ("The path of spending and revenues ... clearly cannot be sustained because the debt-to-GDP ratio spirals out of control after 2030.”).

${ }^{9}$ For an assessment of budget process reform proposals, see Philip G. Joyce \& Robert D. Reischauer, Deficit Budgeting: The Federal Budget Process and Budget Reform, 29 HARV. J. LEGIS. 429 (1992).

${ }^{10}$ The primary constitutional reform proposal has been the proposed Balanced Budget Amendment. See S.J. Res 1, 105th Cong. (1997); S.J. Res. 1, 104th Cong. (1995). In 1995, the Amendment failed in the Senate, effectively one vote short of the needed two-third majority. See 141 Cong. REC. S3310-13 (daily ed. Mar. 13, 1995). The subsequent November, 1996 elections led to an increase in the Republicans' Senate majority, bringing speculation that a balanced-budget amendment might now have enough votes to pass that body. See Eric Pianin \& Guy Gugliotta, Budget Amendment Gets Warmer Climate, WASH. Post, Nov. 11, 1996, at A4. The proposal, however, failed again by one vote. See 143 ConG. REC. S1922 (daily ed. Mar. 4, 1997); David E. Rosenbaum, Republicans' Budget Amendment Is Headed for Defeat in the Senate, N.Y. Times, Feb. 27, 1997, at A1 (reporting Sen. Robert Torricelli's announcement reneging on campaign promise to support Balanced Budget Amendment).

Legal scholars have debated whether a Balanced Budget Amendment would be wise and effective. See Theodore P. Seto, Drafting a Federal Balanced Budget Amendment That Does What It Is Supposed To-And No More, 106 YALE L.J. 1449 (1997) (describing proposed Amendment as potentially unenforceable and as poorly drafted); Donald B. Tobin, The Balanced Budget Amendment: Will Judges Become Accountants? A Look at State Experiences, 12 J.L. \& Pol. 153 (1996) (asserting that judicial intervention in budget matters will bring unintended consequences); Gay Aynesworth Crosthwait, Note, Article III Problems in Enforcing the Balanced Budget Amendment, 83 Colum. L. REv. 1065 (1983); David Lubecky, Comment, The Proposed Federal Balanced Budget Amendment: The Lesson from State Experience, 55 U. CIN. L. REV. 563 (1996) (comparing different states' balanced budget amendments).

${ }^{11}$ The provision is so obscure in Fourteenth Amendment scholarship that no commentator appears even to have taken the trouble to name it. In seeking to revitalize the Clause, this Article at least remedies this neglect.

${ }^{12}$ Even at the turn of the century, treatises on the Fourteenth Amendment ignored the Clause. See, e.g., Henry Brannon, A Treatise on the Rights and Privileges Guaranteed by the Fourteenth Amendment to the Constitution of the United States 7 (1901) (quoting Fourteenth Amendment as containing only Sections 1 and 5).

${ }^{13}$ In this sense, the Clause is assumed to be the Reconstruction analogue of a provision in the original Constitution: “All Debts contracted and Engagements entered into, before the Adoption of this Constitution, shall be as valid against the United States under this Constitution, as under the Confederation.” U.S. ConsT. art. VI., cl. 1. Placing aside the possibility of a lingering debt from the eighteenth century, this provision is no longer 
scars. While the Clause did arise in the peculiar context of Reconstruction, this Article argues that it remains applicable today and that it could transform the Fiscal Constitution ${ }^{14}$ by adding an intertemporal constraint to the budget process. This constraint would enhance congressional power by allowing Congress to tie its own hands with irrevocable budgetary promises, ${ }^{15}$ and accordingly would reduce Congress's power by blocking it from repudiating or jeopardizing such commitments.

Part I argues that the Public Debt Clause applies beyond Reconstruction. Although there are few historical records available to help us discern the Framers' intention, the history of the Clause's adoption shows that Congress did not intend to limit its applicability to Civil War debt, but rather sought to embed fiscal honor within the Constitution. The Supreme Court has considered the Clause in just one case, ${ }^{16}$ but its decision in that case reaffirms the Clause's vitality and legitimizes its future development. Part II argues for a broad reading of the Clause. The language and history of the Clause show that the "public debt" can include more than just bonds, and that formal repudiation need not occur for its validity to have been questioned.

Part III applies the Public Debt Clause to problems in the budget process. The most obvious consequence of taking the Clause seriously would be that a governmental failure to make debt payments, which seemed possible during the budget impasse over the fiscal year 1996 budget, would be unconstitutional. More broadly, the Clause renders unconstitutional the federal debt-limit statute that makes default possible. Beyond fixing a broken budget process, the Public Debt Clause could serve as a partial

operative. However, the decision of the Framers of the Fourteenth Amendment not to echo this provision by using the phrase "before the Adoption of this article," as they chose to echo other provisions in Section 1 of the Fourteenth Amendment, suggests that they sought to establish a broader principle in the first sentence of $\S 4$. The second sentence of $\S 4$, of course, has little applicability today.

${ }^{14}$ For assessments of restrictions that the Constitution imposes on the budget process, see Kate Stith, Congress' Power of the Purse, 97 Yale L.J. 1343 (1988); Kenneth Dam, The American Fiscal Constitution, 44 U. CHI. L. REv. 271 (1977). Professor Dam defines the "Fiscal Constitution" as including "Supreme Court decisions interpreting the Constitution, key framework legislation, and implicit understandings derived from existing practice." Dam, supra, at 271. The irony of this definition is that though it is part of the Constitution and relates to fiscal matters, the Public Debt Clause is not yet part of the Fiscal Constitution.

${ }^{15}$ The economic notion that a government may benefit by "tying its hands," i.e. providing an institutional mechanism that forces a government to stick to its initial policy commitments, has received more attention in the context of monetary than in the context of fiscal policy. See Robert Barro \& David Gordon, Rules, Discretion, and Reputation in a Model of Monetary Policy, 12 J. Monetary ECon. 101 (1983) (developing theory); Francesco Giavazzi \& Marco Pagano, The Advantage of Tying One's Hands: EMS Discipline and Central Bank Credibility, 32 EuR. ECON. REv. 1055 (1982) (applying theory to European Monetary System).

${ }^{16}$ Perry v. United States, 294 U.S. 330 (1935). 
substitute for a Balanced Budget Amendment. More speculatively, the Clause might preclude repudiation of entitlement promises.

Without an enforcement mechanism, the unconstitutionality of various governmental practices under the Public Debt Clause would be irrelevant. Part IV addresses justiciability issues. By protecting bondholders, the Clause designates a class of individuals with standing to challenge the government's compliance with the Clause. Other potential bars to jurisdiction, including sovereign immunity, the political questions doctrine, ripeness, and separation-of-powers considerations, do not preclude judicial involvement.

Some might say that the U.S. budgetary process has operated since the Fourteenth Amendment's ratification in blissful ignorance of the Clause. Constitutional provisions can rise to prominence in unexpected ways, however, and public disgust with "government as usual" 17 could make this an ideal time for enforcing the Clause.

\section{The Continuing Vitality of the Public Debt Clause}

This Part shows that the Public Debt Clause established not a transitional rule for Reconstruction, but a fiscal constraint for all time. Section I.A uses historical evidence to argue that the Framers intended the Clause to be applicable beyond the Reconstruction period. Section I.B reviews the limited jurisprudence addressing the Clause and concludes that it does not contradict and may encourage a broad interpretation. Finally, Section I.C argues that desuetude has not sapped the Clause of its meaning, and that normative considerations may add additional support to this Article's interpretation.

\section{A. The History of the Public Debt Clause}

The Public Debt Clause emerged not from a congressional debate about the dynamics of the Fiscal Constitution, but from a Thirty-Ninth Congress focused on reconstructing a war-ravaged nation. It is not surprising then that no member of the House or Senate commented for the record $^{18}$ on the Clause's consequences for posterity. ${ }^{19}$ This lack of

${ }^{17}$ See, e.g., Brigid Schulte, Disgust at All-Time High, Polls Find, Knight-Ridder News Service, Dec. 19, 1995; Lee Walczak, The New Populism, Business WEEK, Mar. 13, 1995, at 72 (assessing increasing distrust of politicians).

${ }^{18}$ Aside from the Congressional Globe, which recorded statements on the floor of the House and Senate, the primary source of information about the Congress's intent is BENJAMIN B. KENDRICK, THE JOURNAL OF THE JOINT COMMITTEE OF FIFTEEN ON RECONSTRUCTION (1914), which contains the proceedings of the joint House-Senate committee that produced an initial draft of the Fourteenth Amendment.

${ }^{19}$ The limited discussion in Congress on the Fourteenth Amendment is a problem not just for Public Debt Clause scholarship, but for examinations of more prominent parts of the 
articulation does not mean that the Framers sought to modify the Constitution for only the crisis at hand, as some have assumed. ${ }^{20}$ Rather, it demands attention to the evolution of $\S 4$ 's language and the context in which Congress crafted its words. Indeed, the only scholar to examine the Clause's history tentatively concludes that "the intention was to lay down a constitutional canon for all time in order to protect and maintain the national honor and to strengthen the national credit."21 In the context of the Equal Protection Clause, the Supreme Court has recognized the broad applicability of the Fourteenth Amendment. ${ }^{22}$ The historical records suggest that Congress chose to do in the Public Debt Clause what it did in $\S 1$ of the Amendment--set forth a general principle as applicable today as in Reconstruction.

\section{Evolution of the Clause in Congress}

The present version of the Public Debt Clause emerged whole with little explanation during the final Senate floor debate on the Fourteenth Amendment. ${ }^{23}$ While the history is therefore insufficient to answer many questions about the provision, ${ }^{24}$ there are enough clues to justify confidence that the Clause applies to debts incurred after the Civil War. On its face, the provision appears to apply to the entire public debt, including war-related debts but not excluding other debts. Distinctions between the final wording and the language of earlier versions of $\S 4$ suggest that the general wording was not accidental. In particular, the previous version of the Clause ${ }^{25}$

Amendment as well. See, e.g., Jacobus tenBroek, The Antislavery Origins of the FOURTEENTH AMENDMENT 192 (1951) ("Considering the character of the contemplated action and the fact that a constitutional amendment was at stake, very little was said on the floor of either House, and what was said related primarily to the more obviously political sections of the proposal.").

${ }^{20}$ See, e.g., Arthur Nussbaum, Comparative and International Aspects of American Gold Clause Abrogation, 44 YAlE L.J. 53, 85 (1934) (asserting that Public Debt Clause "does not seem to proclaim a principal [sic] of legal philosophy, but to envisage a particular situation existing at the time of its enactment (1866).”). Professor Nussbaum offered no evidence for his interpretation.

${ }^{21}$ Phanor J. Eder, A Forgotten Section of the Fourteenth Amendment, 19 CORNELL L.Q. 1, 15 (1933).

${ }^{22}$ See, e.g., San Mateo County v. Southern Pacific R.R., 116 U.S. 138 (1882) (repudiating theory that Equal Protection Clause related only to blacks).

${ }^{23}$ See Cong. GloBE, 39th Cong., 1st Sess. 3040. The final language was drafted by Sen. Clark, who also synthesized the debt validity and debt repudiation provisions, which were previously two separate sections, into $§ 4$.

${ }^{24}$ As one scholar has concluded in reference to $\S 4$, "We are on an uncharted sea and ... it would be hazardous to venture on any dogmatic assertions.” Eder, supra note 21, at 4.

${ }^{25}$ This version, approved during debate on June 4, 1866, read: "The obligations of the United States, incurred in suppressing insurrection, or in defense of the Union, or for payment of bounties or pensions incident thereto, shall remain inviolate.” CONG. GLOBE, 39th Cong., 1st Sess. 2938-41. 
unambiguously limited the Clause's applicability to debts "incurred in suppressing insurrection." The addition of the word "including" suggests at least a latent congressional preference for a provision of general applicability.

Indeed, $\S 4$ had evolved to its present state through gradual steps of increasing generality. An early version ${ }^{26}$ of $\S 4$ was clearly limited to repudiating the Confederate debt, reflecting the Joint Committee on Reconstruction's apparent lack of concern about the possibility that repudiation of Union debt was imminent. ${ }^{27}$ Congress tinkered with the provision, repudiating debt prospectively from any future insurrections instead of just from the "late rebellion."28 More importantly, Congress added a separate sentence securing the validity of the Union debt. ${ }^{29}$ Recommending this addition, Sen. Howard said that the provision "not only accepts honesty as a principle, but indorses [sic] it as the highest and best policy of the State as well as of individuals." 30

Though a last-minute substitution, the final version of the section hearkened back to the language of an earlier proposed version of the Public Debt Clause that never reached a vote in the Senate. ${ }^{31}$ This version is

${ }^{26}$ Sen. Howard initially proposed a debt repudiation provision as an independent constitutional amendment, which would read:

That the payment of every kind of indebtedness arising or growing out of the late rebellion, contracted or accruing in aid of it or in order to promote it, is forever prohibited to the United States and to each of the states; such indebtedness and all evidences thereof are hereby declared and in all courts and places shall be held and treated as in violation of this Constitution, and utterly void and of no effect.

KENDRICK, supra note 18, at 62.

${ }^{27}$ The Committee, which had jurisdiction over questions related to the readmission of states, gave prominent consideration to debt issues generally in examining a draft of the proposed resolution to readmit Tennessee. The first section of the proposed resolution addressed debt issues, with secession and suffrage provisions relegated to the second through fourth sections. However, the Committee voted to amend the proposal by eliminating language preventing the state from repudiating "any debt or obligation contracted or incurred in aid of the Federal government against said rebellion .... .” KeNDRICK, supra note 18, at 69.

${ }^{28}$ The change to general language was gradual; an April 20 version of the provision introduced by Rep. Stevens referred to "Debts incurred in aid of insurrection or of war against the Union." Id. at 84. The final version replaces "the Union" with "the United States," thus removing any doubt as to the applicability of the second sentence of $\S 4$ to future rebellions.

${ }^{29}$ See supra note 25.

${ }^{30}$ Cong. Globe, 39th Cong., 1st Sess. at 3036. Sen. Howard also stated that the provision was "a proper precaution against the establishment of parties hereafter appealing to the sordid interests and lowest passions of men ....” Id.

${ }^{31}$ The first sentence of the proposal read:

The public debt of the United States, including all debts or obligations which have been or may hereafter be incurred in suppressing insurrection or in carrying on war in defense of the Union, or for payment of bounties or pensions incident to such war and provided for by law, shall be inviolable. 
stylistically much closer to the final language than was the penultimate proposal. ${ }^{32}$ The drafter of the final version therefore probably used this earlier proposal rather than the penultimate proposal as a starting point. Therefore, where the meaning of the earlier proposal is clear and the final version appears to revert to this meaning, the earlier proposal and the final version probably share the same meaning. This inference is especially strong if the penultimate version clearly indicated a meaning different from both the earlier and final version. ${ }^{33}$

In fact, the earlier version differed from the penultimate in two critical ways that suggest it was intended to be generally applicable. First, the earlier version, like the final version, used the non-exclusive word "including" to place war debts within the broader category of the public debt. Second, the last two words of the earlier proposal are "be inviolable" rather than the retrospectively oriented "remain inviolate." The statements of Sen. Wade in support of the earlier proposal also suggest an intent to embed in the Constitution a general economic principle. ${ }^{34}$ Because the earlier proposal was intended to apply beyond Reconstruction and the final version reverted to similar language, the final version too was probably generally applicable. The Congress drafting $\S 4$ chose from a menu of linguistic variants. The subtle but clear distinctions in these variants suggest that Congress meant to make $\S 4$ applicable beyond Reconstruction.

An argument against the applicability of the Public Debt Clause to post-Civil War Debt would likely focus on a single statement by the sponsor of the final language of $\S 4$, agreeing that the new language did not change the effect of the provision. ${ }^{35}$ There are three reasons not to focus too much on this brief comment. First, stylistic changes in constitutional provisions

CONG. GLOBE, 39th Cong., 1st Sess. 2768.

${ }^{32}$ Compare supra text accompanying note 1 , with supra note 25 (penultimate version), and supra note 31 (earlier version).

${ }^{33}$ Ordinarily, evidence from drafts of statutory or constitutional provisions can cut two ways. Either the first version provides evidence of what the drafters meant in the second, or the change in language suggests that the drafters intended to change the underlying meaning. With the Public Debt Clause, however, the existence of a meaning shared by the first and three drafts and a different meaning in the second draft means that both inferences point in the same direction. Both the similarity between the first and third drafts and the difference between the second and third suggest that the drafters intended to recapture the original meaning and discard the second version's meaning in the final version.

${ }^{34}$ While Sen. Wade noted specially that the provision would put "the debt incurred in the civil war on our part under the guardianship of the Constitution," he added that this would "give great confidence to capitalists and will be of incalculable pecuniary benefit to the United States.” Id. at 2769. In other words, the nation would benefit by increasing the security of its bond issues; this allows the country to borrow more cheaply in the future. This benefit is irrelevant for past debt accumulation, suggesting that Sen. Wade saw this version of the Public Debt Clause as providing a prospective benefit.

${ }^{35}$ After Sen. Clark introduced the proposed substitute that was ultimately passed, Sen. Johnson said, "I do not understand that this changes at all the effect of the fourth and fifth sections. The result is the same.” Sen. Clark agreed, “The result is the same.” Id. at 3040. 
are not generally assumed to be without substantive content and thus are not ignored in favor of penultimate drafts. ${ }^{36}$ Second, the senator's statement may merely indicate that the versions would have the same result for the purposes of Reconstruction, since the generalization of the language would have impact only in future times. Third, the Senate rejected a subsequent proposal to revert the provision to its prior language. ${ }^{37}$ The significance of this rejection is unclear, because the proposal focused on changes other than the reversion of wording in $\S 4 .{ }^{38}$ However, the Senate had just voted to accept the current language, so an independent proposal to revert it would probably have failed.

\section{The Political and Economic Context of the Framing}

Perhaps the Public Debt Clause has become obscure because $\S 4$ contains so many implicit references to the Civil War that readers may assume that Congress could not have been concerned about anything else in passing it. However, a congressional desire to impose a permanent prohibition against default makes sense in the economic and political context of Reconstruction. Economically, financial instruments were precarious in the 1860's. The value of U.S. debt tumbled during the Civil War; ${ }^{39}$ while some of the decline may be attributable to the rising interest rates that accompanied the climb in the national debt, the bonds' continuing decline in value as maturity approached suggests skittishness about the possibility that the United States might default. ${ }^{40}$ Congressmen professed the moral necessity of paying the debt, ${ }^{41}$ but perhaps they felt the need to do so partly because it was so high. ${ }^{42}$ A constitutional guarantee provided meaningful assurance to those who might purchase future government debt.

\footnotetext{
${ }^{36}$ See Nixon v. United States, 506 U.S. 224, 231-32 (1993) (rejecting argument that Committee of Style's changes should be ignored in favor of second to last draft, because that would ignore Framers' decision to pass final draft).

${ }^{37}$ See CONG. GLOBE, 39th Cong., 1st Sess. 3040.

${ }^{38}$ Sen. Doolittle's proposal would have both reverted the provision to its prior language and allowed states to ratify some but not all sections of the Fourteenth Amendment. The proposal was defeated, 33-11 with 5 absent. See id.

${ }^{39}$ Ten-year, six-percent bonds issued in 1858 had declined in value $14 \%$ by $1861,36 \%$ by 1862, and $46 \%$ by 1864 . See Douglas B. Ball, Financial Failure and Confederate DEFEAT 132 (1991).

${ }^{40}$ See George T. McCandless, Jr., Money, Expectations, and the U.S. Civil War, 86 AM. ECON. REV. 661 (1996) (arguing that war news was primary determinant of value of Northern and Southern currency).

${ }^{41}$ The House of Representatives had earlier voted 162-1 to approve a resolution calling the public debt "sacred and inviolate" and urging "that any attempt to repudiate or in any manner to impair or scale the debt, shall be universally discountenanced, and promptly rejected by Congress if proposed.” Cong. GLOBE, 39th Cong., 1st Sess. 10.

${ }^{42}$ The debt had climbed from $\$ 64.8$ million in 1860 to $\$ 2.76$ billion in 1866 . See JAMES D. SAvage, Balanced Budgets \& American Politics 288 (1988).
} 
The Public Debt Clause also reflects the Thirty-Ninth Congress's almost religious commitment to hard-money principles. The financial exigencies of the War had led to passage of the Legal Tender Acts ${ }^{43}$ and the resulting issue of greenbacks, though in ordinary fiscal times Treasury Secretary Chase and Congress would never have tolerated the distribution of Treasury notes not convertible to gold or silver. ${ }^{44}$ After the War, Congress passed a resolution, by a vote of 144-6, urging a return to the former monetary regime in which paper was backed by metal. ${ }^{45}$ Although the greenbacks' convenience relative to bank drafts thwarted Congress's resolution to cash them in, ${ }^{46}$ the Thirty-Ninth Congress surely remembered both the difficulty that the Treasury had experienced in borrowing money ${ }^{47}$ and the wartime Congress's fiscal gluttony. The Public Debt Clause served to demonstrate that Congress remained committed to sound financial management.

Underlying the Framers' political concern in $\S 4$ is the ironic electoral calculus that members of the Thirty-Ninth Congress faced. Victory on the battlefields did not bring political security to the Republicans, but rather the prospect that they might lose their hold on Congress. In freeing the slaves, the Emancipation Proclamation ${ }^{48}$ unraveled the Three-Fifths

\footnotetext{
${ }^{43}$ Act of Feb. 25, 1862, ch. 33, 12 Stat. 345; Act of July 11, 1862, ch. 142, 12 Stat. 532; Act of Mar. 3, 1863, ch. 73, 12 Stat. 709.

${ }^{44}$ See generally Bray HAMmOND, SOVEREIGNTY AND AN EMPTY PURSE: BANKS AND POLITICS IN THE CIVIL WAR 165-229 (1970) (describing Treasury and Congress's reluctant accession to Legal Tender Acts); Margaret G. Myers, A Financial History of the United States 150 (1970) (describing Chase as “a hard-money man, as suspicious of bank paper as Jackson and Benton had been”). Even after Treasury Secretary Chase became Chief Justice Chase, he never became entirely comfortable with the Legal Tender Acts, which the Supreme Court initially found unconstitutional in Hepburn v. Griswold, 75 U.S. (8 Wall.) 603 (1870), overruled by Legal Tender Cases, 79 U.S. (12 Wall.) 457 (1871). See generally Kenneth W. Dam, The Legal Tender Cases, 1981 Sup. CT. REV. 367.

${ }^{45}$ See Cong. Globe, 39th Cong., 1st Sess. 75.

${ }^{46}$ Congress faced "a sudden, impatient, popular belief--quite opposite to the Jacksonian hardmoney notions previously prevailing and to the intent of the war-time advocates of the notes-that an abundant currency based simply on federal credit and the country's worth was required for the general good.” HAMMOND, supra note 44, at 253.

${ }^{47}$ Because there had been no national bank since the Jackson Administration, the Lincoln Administration could not simply auction off debt to the highest bidder. Rather, the federal government resorted to commercial banks. Despite high levels of reserves, these banks were hesitant about lending to the federal government, because "they faced a revolutionary change in their business, with a different kind of borrower.” HAMmOND, supra note 44, at 76. The problem was exacerbated by federally imposed specie rules, which required the federal government to take physical control of gold when it borrowed, instead of merely receiving credit on the bank's books like other borrowers. Id. at 59-70. The amount borrowed grew so high that the banks were unable to meet the government's demand for specie, resulting in delays in the United States's payment of creditors, employees, and suppliers. Id. at 162.

${ }^{48}$ While the Thirteenth Amendment's ratification in 1865 assured the immediate goal of the Proclamation itself, the purpose that unifies the various provisions of the Fourteenth Amendment was the securing of the remaining "fruits of the war." See KENDRICK, supra note 18, at 266-67 (listing civil rights and debt provisions among victory spoils that all
} 
Compromise ${ }^{49}$ and thus increased the population base that determined the South's representation. ${ }^{50}$ Repudiation of rebel debt was consistent with Republican interpretations of existing law, ${ }^{51}$ but a Democratic Congress conceivably might have honored the debt or might even have repudiated the Union debt. To minimize the chance of a Democratic resurgence, the Congress included Sections 2 and 3 in the Fourteenth Amendment. ${ }^{52}$ Thus, the probability of repudiation of the Union debt in the absence of $\S 4$ was small. ${ }^{53}$ But the insertion of the uncontroversial ${ }^{54} \S 4$ did more than provide insurance precluding a future Congress from retreating on the Thirty-Ninth Congress's commitment to repay the national debt. ${ }^{55}$ Just as important, the provision cemented the North's military victory with a rhetorical one by declaring Confederate obligations (and thus the Confederacy itself) "illegal and void" and by elevating the United States to the fiscal high road.

Republicans sought); see also TENBROEK, supra note 19, at 184 (noting that Congressmen wanted to place achievements of civil rights bills beyond reach of shifting Congressional majorities).

${ }^{49}$ See U.S. Const. art. I, § 2, cl. 3 (counting slaves as three-fifths persons for purpose of representation in House).

${ }^{50}$ Rep. Conkling estimated that the South would gain twelve representatives by Emancipation, in addition to the eighteen representatives that the South previously was allotted on account of its slave population. CoNG. GLOBE, 39th Cong., 1st Sess. 356-59 (1866). In addition, each rebel state's entitlement to two senators upon readmission was beyond even the power of a constitutional amendment. See U.S. ConsT. art. V (prohibiting amendments depriving unconsenting states of equal suffrage in Senate).

${ }^{51}$ See, e.g., CONG. GLOBE, 39th Cong., 1st Sess. 3036 (arguing that invalidity of rebel debt reflected common law principle that agreements founded on immoral consideration are unenforceable). Rep. Miller, however, had earlier noted that if the rebel states were considered to have left the Union and were then reannexed, principles of international law would demand assumption of the states' debts. Id. at 2087.

${ }^{52}$ Section 2 provided that representation in the House would be proportionately diminished when males over 21 years old were excluded from the franchise. Section 3 prohibited many Confederate officers and officials from membership in Congress.

${ }^{53}$ Arguing against what became $\S 4$, Sen. Saulsbury asked, "Does the Senator from Nevada say that the Democratic party of this country would, if they had it in their power, repudiate the national debt or would assume the confederate debt? I should like a frank answer." Sen. Stewart of Nevada did not answer the question. Cong. Globe, 39th Cong., 1st Sess. 2800 (1866). See also id. at 2940 (statement of Sen. Hendricks) ("Who has attacked public credit, or questions the obligation to pay the public debt?"). Testimony before the Joint Committee, however, indicated that Southerners hoped to repudiate the Union debt if the Democrats regained Congress, but would settle for like treatment of Union and Confederate debt. KENDRICK, supra note 18, at 283.

${ }^{54}$ Section 4 was the subject of little comment on the floor of Congress largely because of its uncontroversiality. After extensive discussion of other provisions of the Amendment, Rep. Stevens noted simply, "The fourth section, which renders inviolable the public debt and repudiates the rebel debt, will secure the approbation of all but traitors.” CONG. GLOBE, 39th Cong., 1st Sess. 3148; see also id. at 2530 (statement of Sen. Randall).

${ }^{55}$ Congress acted on its intent to repay much of the Civil War debt at about the same time that it was considering the Fourteenth Amendment by passing a statute permanently appropriating funds to pay off much of it. See Act of May 2, 1866, ch. 70, § 2, 14 Stat. 41, $41-42$. 


\section{B. Jurisprudence on the Public Debt Clause}

The Supreme Court has expounded on the Public Debt Clause just once, in Perry v. United States. ${ }^{56}$ Subsection I.B.1 narrates the facts and holding of the case, and Subsection I.B.2 argues that while Perry and subsequent decisions are inconclusive, they do not threaten and may strengthen the Clause's vitality.

\section{Perry v. United States}

Perry was one of the Gold Clause Cases, which concerned bonds issued by Congress that included a "gold clause" stipulating, "The principal and interest hereof are payable in United States gold coin of the present standard of value." 57 When gold subsequently appreciated vis-à-vis the dollar, Congress retreated, finding "payment in gold or a particular kind of coin or currency [to be] against public policy," 58 and providing for payment in dollars only. Perry, a bondholder, sued for the dollar equivalent of the gold he would have received at the earlier exchange rates.

The Supreme Court held the Public Debt Clause applicable:

While this provision was undoubtedly inspired by the desire to put beyond question the obligations of the Government issued during the Civil War, its language indicates a broader connotation. We regard it as confirmatory of a fundamental principle, which applies as well to the government bonds in question, and to others duly authorized by the Congress, as to those issued before the Amendment was adopted. ${ }^{59}$

The Court used the Public Debt Clause as support for a structural argument that the Constitution did not allow the federal government to change the terms of its bonds. The Court rested most heavily on the clause of the unamended Constitution authorizing Congress "to borrow Money on the credit of the United States." 60 The Court noted, "The binding quality of the promise of the United States is of the essence of the credit which is so pledged...." Having this power to authorize the issue of definite obligations ... the Congress has not been vested with authority to alter or destroy those obligations." 61

\footnotetext{
56294 U.S. 330 (1935).

${ }^{57}$ Id. at 347 .

${ }^{58}$ Joint Resolution of June 5, 1933, 48 Stat. 113.

${ }^{59} 294$ U.S. at 354.

${ }^{60}$ U.S. CONST. art. I, § 8, cl. 2.

61294 U.S. at 353.
} 


\section{Perry’s Jurisprudential Vitality}

The Supreme Court has not had the opportunity to reconsider Perry's assessment of the Public Debt Clause, so it is unclear whether a future Court would agree that the Clause was applicable beyond the Civil War. An attack on Perry's relevance would note a set of recent lower-court cases finding the Public Debt Clause inapplicable, the peculiar timing of Perry, and the decision's primary reliance on the "borrow Money" Clause. None of these arguments seriously undermines Perry, however. In the end, of course, courts might or might not adopt this Article's interpretation of the Clause, but there is nothing in the case law that would require a court to find the Clause inapplicable or to reject a broad reading of the Clause.

Several federal appellate courts in 1989-90 declined to apply the Clause in cases involving a federal program providing reinsurance to statedesignated student loan guarantee agencies. ${ }^{62}$ After Congress created new provisions with which several agencies failed to comply, the Secretary of Education withheld guarantee payments. Because the agreements with the agencies bound them to any changed statutes or regulations ${ }^{63}$ and allowed the Secretary to punish violations with such withholdings, the courts probably correctly found that no debt was violated. ${ }^{64}$ Commenting on the Clause, two appellate courts implied that it remained applicable, ${ }^{65}$ while two district courts noted the Clause's Civil War origins and suggested it applied only to bond debt. ${ }^{66}$ None of the decisions carefully assesses the history or language of the Clause, so it is difficult to determine to what extent the courts would have agreed with this Article's arguments. But no court argued that Perry should be overruled, thus suggesting that it remains good law.

Perry was decided at the height of the constitutional crisis between the Roosevelt Administration and the Court over new Deal legislation, two years before the "switch in time that saved nine." 67 In post-1937 cases, the Court backed away from earlier activist stances limiting the government's

\footnotetext{
${ }^{62}$ See Great Lakes Higher Educ. Corp. v. Cavazos, 911 F.2d 10 (7th Cir. 1990); Ohio Student Loan Comm'n v. Cavazos, 900 F.2d 894 (6th Cir. 1990) (reversing district court application of Clause); Colorado v. Cavazos, Civ. A. No. 88-C-207, 1990 WL 367621 at *5 (D. Colo. Aug. 21, 1990); Delaware v. Cavazos, 723 F. Supp. 234 (D. Del. 1989), aff'd 919 F.2d 137 (3d Cir. 1990).

${ }^{63}$ See, e.g., Great Lakes, 911 F.2d at 12 n.1.

${ }^{64}$ This accords with an interpretation of the Clause as allowing Congress to reserve the right to modify its debt. See infra Section II.C.

${ }^{65}$ See Great Lakes, 911 F.2d at 17 ("This section is only brought into play when some state or federal government agency questions a debt.”); Ohio Student Loan, 900 F.2d at 902 ("[B]ecause we find no abrogation of the 'contract' in the instant case, we conclude that there was no violation of section four of the Fourteenth Amendment.”).

${ }^{66}$ See Colorado v. Cavazos, 1996 WL at *5; Delaware v. Cavazos, 723 F. Supp at 244-45.

${ }^{67}$ See generally David P. Currie, The Constitution in the Supreme Court: The New Deal, 1931-1940, 54 U. CHI. L. REv. 504 (1987) (discussing Court activism and retrenchment).
} 
ability to craft economic policy. ${ }^{68}$ But this Article's reading of the Public Debt Clause is hardly comparable to the Court's activist interpretation of the Fourteenth Amendment's Due Process Clause. Moreover, the Perry Court appeared determined not to upset governmental policy and ultimately did not award Perry damages. Because there was no free domestic market for gold, the majority reasoned, Perry would not have been able to sell any gold on the hypothetical world market on which his calculations were based. ${ }^{69}$

That the Perry Court's analysis of the Public Debt Clause was one support for a broader argument that the Constitution precludes debt repudiations does not narrow its relevance. Just because there are additional reasons that the repudiation in Perry was unconstitutional does not change that, according to the Court, the Public Debt Clause confirmed the unconstitutionality of repudiation. Moreover, although Perry concerns only direct repudiation of bonds, its holding lends credence to Part II's expansive interpretation of the Public Debt Clause. For if the Constitution already banned debt repudiation, then restricting the Public Debt Clause to outright repudiation of bonds, rather than allowing it to encompass non-bond obligations or extend to actions placing debts into question, would be redundant.

\section{C. $\quad$ Interpreting the Public Debt Clause Today}

This Part so far has engaged originalist, textualist, and precedential methodologies to interpret the Public Debt Clause. There are many approaches to constitutional interpretation, however, and the Clause may be vulnerable to minimalist construction by those who would assess it by relying on historical practice or on normative considerations. After all, Perry was the only exception to the otherwise uneventful history of the Clause, and though Part III of this Article suggests that the Clause could reform the budget process, the practices that may need reform have long, largely unquestioned histories. Moreover, if the Public Debt Clause would disturb the tranquil continuity of these practices, perhaps it is best to leave it alone. Both of these claims are contestable, however, and the following two subsections address critiques of the Public Debt Clause that focus on desuetude or on normative considerations.

\footnotetext{
${ }^{68}$ See, e.g., Ferguson v. Skrupa, 372 U.S. 726, 730 (1963) ("We have returned to the original constitutional proposition that courts do not substitute their social and economic beliefs for the judgment of legislative bodies ....").

${ }^{69} I d$. at 357. Four dissenters argued that the government ought to pay damages. Id. at 369-70 (McReynolds, J., dissenting). See also Currie, supra note 67, at 536 n.161 (calling finding of no damages "bizarre”).
} 


\section{Desuetude}

Concerns about desuetude are generally less applicable in a constitutional context than in a statutory one. ${ }^{70}$ When a statute falls into disuse, it may no longer reflect the consensus of society. ${ }^{71}$ Constitutional provisions are inherently countermajoritarian, binding one generation to at least the words chosen by another. In addition, while an outdated criminal law may be enforced arbitrarily, ${ }^{72}$ this danger does not inhere in constitutional law. Perhaps recognizing these arguments, the Supreme Court has held that longstanding government practice does not waive a constitutional violation. ${ }^{73}$

In some contexts, the potentially destabilizing nature of constitutional adjudication presents a unique desuetude concern not generally applicable to statutory construction, ${ }^{74}$ but revitalization of the Public Debt Clause does not threaten the existing constitutional order. Active reconsideration of some obscure constitutional provisions might be dangerous because those provisions are so open-ended that if the courts were to consider them, damaging uncertainty about the structure of government would result. For example, the Constitution's Guarantee Clause $^{75}$ could conceivably be interpreted to disallow a wide range of state practices viewed as undemocratic. ${ }^{76}$ Even if such an interpretation were correct, adjudication of such claims could mean that the structure of state governments would be modified whenever the composition of the Supreme Court changed and constitutional doctrine surrounding the Clause evolved. Such considerations may underlie the Supreme Court's holdings that

\footnotetext{
${ }^{70}$ For arguments that obsolescent statutes should be nullified because of desuetude, see Guido Calabresi, A Common Law for the Age of Statutes (1982); Corey R. Chivers, Desuetude, Due Process, and the Scarlet Letter Revisited, 1992 UtAH L. ReV. 449.

${ }^{71}$ See CALABRESI, supra note 70, at 2, 21.

${ }^{72}$ See, e.g., Alexander M. Bickel, The Least Dangerous Branch: The Supreme Court AT THE BAR OF Politics 153 (1962) (arguing that obsolete statutes are subject to discriminating enforcement).

${ }^{73}$ See INS v. Chadha, 462 U.S. 919, 942 (1983).

${ }^{74}$ Destabilization was potentially of particular concern in Chadha, because a wide range of statutory schemes assumed the constitutionality of the legislative veto, but the Court found the veto unconstitutional nonetheless.

${ }^{75}$ U.S. CONST. art. IV, § 4 ("The United States shall guarantee to every State in this Union a Republican Form of Government ....”)

${ }^{76}$ See, e.g., Debra F. Salz, Note, Discrimination-Prone Initiatives and the Guarantee Clause: A Role for the Supreme Court, 62 GEO. WASH. L. REV. 100 (1993) (arguing that Colorado's Amendment 2 violated the Guarantee Clause); see also Akhil Reed Amar, The Central Meaning of Republican Government: Popular Sovereignty, Majority Rule, and the Denominator Problem, 65 U. Colo. L. REV. 749 (1994) ("The concept [of Republican Government] is indeed a spacious one, and many particular ideas can comfortably nestle under its big tent.”).
} 
Guarantee Clause claims are not justiciable. ${ }^{77}$ Because passage of a statute requires the approval of both houses of Congress and approval by the President (or a veto override), congressional resolution of Guarantee Clause claims may be more final than Supreme Court rulings, and it may therefore be wise for the courts not to hear constitutional claims where finality in constitutional principle is particularly important. ${ }^{78}$ Even more importantly, an invalidation of a state practice might lead to questioning of statutes passed as a result of that practice, leading to considerable confusion.

Though the Public Debt Clause could help shape the Fiscal Constitution, its potential is not destabilizing. A ruling that a particular statute violated the Public Debt Clause would result simply in the invalidation of that statute. The Public Debt Clause implicates the powers of Congress, but not the structure of government, and it thus has no more destabilizing potential than any other constitutional provision. In addition, the Clause protects against government action that presumably would occur rarely even in the Clause's absence. That the Supreme Court has not regularly applied the Clause does not mean that Congress has relied on its ability to ignore its debt obligations; to the contrary, the Clause's dormancy indicates that Congress generally has recognized its moral, and perhaps constitutional, duty to pay its debts.

\section{Normative Arguments}

Normative concerns need not entrench the status quo, and there is thus no reason to assume that it is best to leave government running as it has. A full normative assessment of a principle requiring the government to follow through on its fiscal promises is beyond the scope of this Article. The basic case for such a provision, however, is simple: By allowing Congress to tie its own hands, the Clause increases the credibility of congressional promises and improves the nation's credit rating. People will be less inclined to hold and purchase government debts if they believe that the government will not honor those obligations. ${ }^{79}$

\footnotetext{
${ }^{77}$ See Luther v. Borden, 48 U.S. (7 How.) 1 (1849) (holding that determination of which of two rival claimants was rightful government of Rhode Island required congressional resolution); Pacific States Tel. \& Tel. Co. v. Oregon, 223 U.S. 118 (1912) (reaffirming that Guarantee Clause claims are not justiciable); see also Nixon v. United States, 506 U.S. 224, 253 (1993) (Souter, J., concurring) (arguing that political questions doctrine is based on prudential concerns).

${ }^{78}$ The counterargument is that the Supreme Court may decline to overrule constitutional holdings where there is a strong social interest in finality. Cf. Planned Parenthood v. Casey, 503 U.S. 833, 854 (1992) (arguing that constitutional stare decisis has particular force where a "rule is subject to a kind of reliance that would lend a special hardship to the consequences of overruling”).

${ }^{79}$ The counterargument is also simple: What happens if Congress ties its hands and lives to regret it? Under this Article's interpretation of the Public Debt Clause, Congress must refrain from crafting policies that would violate the Clause, even if those policies would be in the
} 
Moreover, this Article is premised on a belief that several areas of congressional budget practice require reform. Admittedly, this normative basis is not perfectly aligned with the values that the Public Debt Clause protects. In a sense, Part III uses the principle of fiscal honor as the fount of a legal argument for the related but distinct principle of sound fiscal management. A normative argument against either principle might provide a counterweight to this Part's historical and textual interpretation of the Public Debt Clause, but accepting these principles adds purpose and urgency to this Part's historical and textual interpretations.

\section{The Meaning of the Public Debt Clause}

The history of the Public Debt Clause contributes only to an understanding of the temporal scope of the provision. Assuming the Clause remains in force today leaves additional questions: What constitutes the "public debt"? And what type of action entails a questioning of the debt's validity? These questions, never addressed in a committee report or on the floor of the Senate, are inherently difficult. One response might be to construe the Public Debt Clause as narrowly as possible, ${ }^{80}$ but the language of $\S 4$, literally read using standard principles of construction, ${ }^{81}$ demands a broad application. As Section II.A argues, the Clause encompasses not just bonds, but also any financial obligation stemming from an agreement. Meanwhile, Congress need not repudiate a debt to trigger the Clause; Section II.B shows that if Congress indirectly makes it so that a debt will not be paid, it has violated the Clause.

national interest. Ultimately, a full normative assessment of the Clause requires balancing its benefits in improving congressional credibility and its costs in restricting Congress's policy options.

${ }^{80}$ The narrowest possible construction of Public Debt Clause would read it out of the Constitution altogether, by applying it only to Civil War debt. The Supreme Court, of course, has never adopted the principle that ambiguity should always be resolved by limiting constitutional provisions' scope to circumstances that they unambiguously cover. $C f$. 1 JOSEPH STORY, COMMENTARIES ON THE CONSTITUTION § 405 (1870) (noting need to resolve ambiguities in Constitution by selecting interpretation that "best harmonizes with the nature and objects, the scope and design of the instrument.”).

${ }^{81}$ This Section adopts three interpretive principles to resolve ambiguity. First, interpretations that would read words or phrases out of the Clause are rejected in preference for interpretations that consider the meaning of each word. See Marbury v. Madison, 5 U.S. (1 Cranch) 137, 174 (1803) ("It cannot be presumed that any clause in the constitution is intended to be without effect ....”). Second, the presence of a particular word or phrase in the Clause leads to the assumption that the Framers intended to use that word rather than another that would correspond to an alternative reading. See INS v. Cardoza-Fonseca, 480 U.S. 421, 433 n.12 (1987) (noting strong presumption that Congress expresses its intent through language it chooses). Third, the meaning of words is construed by reference to the surrounding words. See, e.g., Neal v. Clarke, 95 U.S. 704, 709 (1877) (discussing canon known as noscitur a sociis). 


\section{A. Obligations Included Within the Public Debt}

To the modern economist, the words "public debt" may connote only bond obligations; in today's budget process, "public debt" is a technical term with a narrow scope.82 Black's Law Dictionary, however, defines the public debt as "[t]hat which is due or owing by the government of a state or nation," 83 and the words of the Public Debt Clause suggest that the Framers were protecting a similarly broad class of obligations. A key to understanding the scope of the provision lies in the phrase, "including debts incurred for payment of pensions and bounties for services in suppressing insurrection or rebellion." The use of the word "including" rather than "in addition to" or "and of" shows that the enumerated rebellion-related debts ${ }^{84}$ delineate the expanse of the phrase "public debt" rather than annexing an additional category of "debts" to it. In other words, the "including" phrase indicates that the Framers conceived the "public debt" as including not just financial instruments, but also such promises as war pensions and bounties. ${ }^{85}$ This interpretation is further supported by the use of the words "debts incurred" rather than, for example, "notes and contracts." The word "debts" draws a parallel with the phrase "public debt," suggesting that the Framers naturally thought of pensions and bounties as being part of the "public debt."

This Article construes the "public debt" to include the ordinary pensions of government employees and similar government commitments.

\footnotetext{
${ }^{82}$ The federal government currently defines "public debt" to include only bond obligations issued by the Treasury; debt issued by administrative agencies is tallied separately as “agency debt." See Department of the Treasury, Budget of the United States Government: Analytical Perspectives, Fiscal Year 1996, at 188 (1995) [hereinafter Analytical Perspectives].

${ }^{83}$ BLACK's LAW Dictionary 404 (6th ed. 1990). See also Reeside v. Walker, 52 U.S. (11 How.) 272, 284 (1850) (defining "public debt" as including "debts of every description, without reference to their origin.”).

${ }^{84}$ One might construe the phrase "pensions and bounties for services in suppressing insurrection or rebellion" by applying the "for" phrase to the word "bounties" but not to "pensions." This approach would be consistent with the general interpretive rule that a phrase applies only to its immediate antecedent. See, e.g., Virginia v. Browner, 80 F.3d 869, 877 (4th Cir. 1996). This interpretation would mean that even if the public debt did not ordinarily include pensions, these are specifically protected by the Public Debt Clause, whether or not insurrection-related. However, this construction seems forced, considering the parallelism of the words "pensions" and "bounties."

${ }^{85}$ The irony of this interpretation is that the presence of the "including" phrase may explain why those not scrutinizing $\S 4$ might conclude that the entire section is no longer relevant. The reference to insurrection or rebellion connects the Public Debt Clause with the second sentence of $\S 4$, which no longer is generally applicable. But once it is conceded that the words "validity of the public debt" have general applicability, as argued in Section I.A, supra, the "including" phrase may be seen as narrowing rather than widening the Public Debt Clause only if the enumerated items are read exclusively. Such a reading is implausible, however, since the Clause surely encompasses at least formal debt instruments, which are not specifically enumerated in the "including" phrase.
} 
This construction might appear to read out of the Clause the phrase limiting pensions and bounties to those incurred in suppressing insurrection. This language was essential, however, because the South claimed that secession was legal and the suppression of it illegal. Without an unambiguous syntactic indication that the war-related debts were part of the public debt authorized by law, the Public Debt Clause would have left open the possibility that a Democratic Congress could have repudiated the Union's Civil War bonds as illegal and not part of the public debt. This appears to explain the awkward location of "authorized by law" in between the "including" phrase and "the public debt of the United States." 86 The Framers sought with that location to clarify that the Civil War origins of "pensions and bounties" would not keep them out of the "public debt."

The phrase "authorized by law" and the word "debt" provide plausible limits on the scope of the Public Debt Clause; while Part III of this Article does not depend on these limits, it is useful to see that this Part's construction of the Clause need not radically change the legal order by forcing Congress to follow through on all of its earlier intentions. First, a governmental promise is "authorized by law" only if it is contained in a congressional statute. ${ }^{87}$ Second, a debt is "[a] sum of money due by certain and express agreement." 88 Applying this definition to the Public Debt Clause, the United States incurs a public debt only if a statute embodies an agreement, or, more restrictively, only if the government issues a written agreement. ${ }^{89}$ Since a gratuitous promise does not ordinarily constitute a legally enforceable agreement, the Clause could be further limited to

\footnotetext{
${ }^{86}$ If “authorized by law" were moved after the "including” phrase, it could be seen as a limit on the scope of "pensions and bounties."

${ }^{87}$ The phrase "authorized by law" thus applies a common-sense limitation to the Public Debt Clause that is also found in the law of government contracts, declaring contracts signed by government employees unenforceable if those employees were unauthorized to sign them. See, e.g., United States v. Amdahl Corp., 786 F.2d 387, 392 (Fed. Cir. 1986). In addition, the omission of the words "or equity" reinforces the Public Debt Clause's exclusion of obligations or claims.

An alternative construction of the phrase "authorized by law" would be that the phrase restricts the Clause's applicability to those debts that had already been authorized before the Amendment's adoption. Two factors militate against this reading. First, the phrase "authorized by law" is more naturally construed as a present participial phrase. Cf. Linsalata v. Clifford, 290 F. Supp. 338, 342 (S.D.N.Y. 1968) (defining phrase "authorized by law" in contractual context to contemplate subsequently enacted statutes). Second, if the Framers had intended explicitly to limit the Clause's temporal applicability, they could easily have indicate this intent clearly, for example with the phrase "heretofore accumulated."

${ }^{88}$ BLACK's LAW DiCTIONARY 403 (6th ed. 1990).

${ }^{89}$ This restriction suggests that the government cannot become an involuntary debtor for Public Debt Clause purposes through commission of a tort on an individual with which it does not have a contract. In other words, the Public Debt Clause does not override the government's sovereign immunity in tort suits, $c f$. Dalehite v. United States, 346 U.S. 15 (1953) (accepting statutory immunity of United States in tort suit), or require that the government become an involuntary debtor.
} 
governmental promises made in exchange for good consideration. ${ }^{90}$ The requirement of an agreement honors $\S 4$ 's distinction among debts, obligations and claims. While the Public Debt Clause itself uses only the word "debt," the second sentence of $\S 4$ uses the terms "debt or obligation" and the phrase "claim for the loss or emancipation of any slave." By including only the first of these within the public debt, the Public Debt Clause excludes money that the United States ought to pay by virtue merely of a moral obligation. ${ }^{91}$

\section{B. Congressional Actions Triggering the Clause}

Once Congress makes a promise that becomes part of the public debt, its "validity ... shall not be questioned." 92 But questioned by what? A nihilistic interpretation would append to the Clause "by this Section," thus reducing it to a nullity, but the language of $\S 4$ makes this construction insupportable. ${ }^{93} \mathrm{~A}$ better interpretation, therefore, is that no state action may question a debt's validity. This does not resolve, however, what "questioned" means. Dismissing the Lafayette Park protester's interpretation of the word leaves two possibilities. "To question" could mean either "to repudiate" or "to jeopardize." As will become clear in Part III, this distinction is important. The following subsection conceptualizes the choice between these alternatives, and the three subsections that follow mount an affirmative case for the preferability and the manageability of the latter.

\footnotetext{
${ }^{90}$ Thus, a statute providing all Californians with a written promise of annual payments of $\$ 500$ in perpetuity might not create a public debt.

${ }^{91}$ This analysis does not resolve the question of whether a moral obligation may rise to the level of a moral consideration by virtue of a Congressional statute. For example, if Congress had passed a statute promising to give \$500 monthly to Oliver Sipple, credited with saving the life of President Ford, would that promise have become part of the public debt? See, e.g., Hawkes v. Saunders, 98 Eng. Rep. 1091 (1782) (providing classic statement of "moral consideration" contract doctrine).

${ }^{92}$ The language echoes the words of the Speech and Debate Clause: “The Senators and Representatives shall ... be privileged from Arrest during their Attendance at the Session of their respective Houses ... and for any Speech or debate in either House, they shall not be questioned in any other Place.” U.S. ConST. art. I, § 6, cl. 1 (emphasis added). Whether this was intentional or coincidental, it does not much help, since questioning a congressman does not seem analogous to questioning the public debt.

${ }^{93}$ First, it is implausible that the Framers could have seen the need to clarify that the second sentence of $\S 4$ does not invalidate the Union debt, since that sentence clearly invalidates only debts "incurred in aid of insurrection or rebellion against the United States." Second, the use of the imperative "shall" instead of "is" removes the possibility that the first sentence of $\S 4$ merely comments on the second.
} 


\section{Possible Levels of Generality}

The question is at what level of generality the Framers drafted the Public Debt Clause. ${ }^{94}$ A provision protecting only Civil War Union debt would be a low level of generality. By establishing that the Clause does not apply only to Civil War debt, Section I.A rejected this possibility. An intermediate level of generality would be a permanent ban on governmental failure to honor debts. Finally, a high level would be a prohibition not only of governmental failure to make payments on a debt, but also of government action that will ultimately lead to such failure. ${ }^{95}$ Only the high level comes into play when Congress passes a statute that will cause default on a debt unless a future Congress changes the statute..$^{96}$

The following subsections argue for the high level of generality by discussing the Clause's language and historical context. Three factors should be kept in mind in assessing this evidence. First, as defined so far, "jeopardization" and "repudiation" 97 differ only in timing: Congress jeopardizes debts as soon as it places the government on the road to default, but repudiation occurs only once Congress fails to change course and the government reaches the end of that road. There are, however, other ways one might define "repudiation," and thus other ways to conceptualize the difference between the intermediate and high levels of generality. In particular, "repudiation" could refer to government action that intentionally leads to debt nonpayment. ${ }^{98}$ However, there is no reason to read an

${ }^{94} \mathrm{Cf}$. Michael J. Klarman, Brown, Originalism, and Constitutional Theory: A Response to Professor McConnell, 81 VA. L. REV. 1881, 1926-28 (1995) (discussing level-of-generality problem in context of Equal Protection Clause).

${ }^{95} \mathrm{At}$ an even higher level of generality would be a general requirement of sound financial management, but this is clearly too general because the text of the Clause is concerned only with "the public debt.” Part II of this Article attempts to achieve some aspects of this general goal by identifying practices threatening the validity of the debt. This Article does not attack other governmental practices that might be fiscally undesirable, such as taxation policies that arguably discourage savings, because these practices are unrelated to the public debt.

${ }^{96}$ For example, suppose Congress were to repeal a statute providing for the automatic payment of a debt due a number of years hence. Under the high level of generality, the statute would be unconstitutional, since it jeopardizes the debt by depending on a future Congress to unrepeal the statute. Under the intermediate level of generality, the repeal statute is constitutional; an unconstitutional event would occur only once the government failed to restore the statute in time to make the payment.

${ }^{97}$ This Article uses these words as shorthand references for the timing distinction, but different definitions of these words are possible. For example, "repudiation" might be defined to occur only when a statute explicitly states that a debt will not be paid. Under this definition, repudiation would occur in the example of note 96 as soon as the repeal statute was passed. But if the government failed to make a payment even though a statute required it, that would not constitute repudiation under this definition. Though this is a plausible definition of "repudiated," it is not a plausible interpretation of "validity . . shall not be questioned.” See also infra note 110; infra Subsection II.B.2.c.

98“Repudiation" might also refer to action directly leading to debt nonpayment. However, assessing the directness of a congressional action's effect on debt really involves assessing 
intentionality requirement into the Public Debt Clause, especially since assessment of congressional motive is a disfavored method of interpretation. ${ }^{99}$ Moreover, much of the evidence that militates against the intermediate level of generality as defined above also militates against alternative definitions of the intermediate level. ${ }^{100}$

Second, there is no smoking gun. Probably, the Framers did not consider the distinction between the intermediate and high levels directly, and the proper inquiry is thus which level of generality is more consistent with the tenor of the Clause and the purposes of Congress. The answer turns in part on whether Congress envisioned the Clause as a technical rule allowing bond-holders to recover in court after missed debt payments or as a more amorphous commitment by the government to ensuring the debt's validity. If the Framers intended the Clause only as a technical ban on nonpayment, the intermediate level of generality is the right one. But if the Framers intended it as a statement of a broad principle constraining Congress, the high level is preferable, because that level identifies a violation of the Clause when Congress contravenes the principle rather than when this contravention affects debt-holders. ${ }^{101}$

Third, it is important to avoid making reflexive assumptions. There is no default rule that constitutional provisions should be interpreted as narrowly as possible. The advocate of the high level of generality would bear the burden of proof only if there were some a priori evidence suggesting that the Framers intended the Public Debt Clause to be narrow. ${ }^{102}$

timing and intentionality. Saying that a congressional action directly affects a debt means either that the action affects the debt right away or that Congress meant to legislate about debt rather than about something else. While the word "directness" might refer to some combination of these, there is no reason to consider directness independently of timing and intentionality issues.

${ }^{99}$ See, e.g., Eastland v. United States Servicemen's Fund, 421 U.S. 491, 508 (1975) (“Our cases make clear that in determining the legitimacy of a congressional act we do not look to the motives alleged to have prompted it.”); United States v. O’Brien, 391 U.S. 367, 383-84 \& 383 n.30 (noting that Court will generally avoid inquiry into congressional intent in constitutional cases because different legislators may have different motives in passing legislation).

${ }^{100}$ See infra notes 104,107 , and 112 ; text accompanying notes $115-116$ and 121-122.

${ }^{101} \mathrm{~A}$ ban on nonpayment furthers the principle of debt validity, but not enough to meet the demands of a general principle. If Congress fails to ensure the validity of debts, the courts might be unable to help, and the need to resort to the courts undermines confidence in debt issues. See infra note 118. Moreover, assuming that Congress did not have a specific technical ban in mind, there is no reason to read into the Clause a distinction between actions repudiating and actions jeopardizing debts. Both type of actions mean that Congress has failed to ensure the debt's validity, and restricting the Clause to the former entails an assumption that the Clause directly constrains the courts but not Congress.

${ }^{102}$ If one were (foolishly) to guess at a level of generality without looking at the Clause's language or history, the high level would seem more plausible than the intermediate. First, the fact that the Framers clearly rejected the low generality level suggests a preference for more general provisions. Second, the Framers wrote $\S 1$ of the Amendment at perhaps the broadest level of generality imaginable. See, e.g., McDonald v. Santa Fe Trail Transp. Co., 


\section{Linguistic Evidence}

The words of the Public Debt Clause are consistent with an interpretation that bars statutes jeopardizing the validity of debts. First, the verb "to question" is closer to the verb "to jeopardize" than it is to the verb "to repudiate." Second, the passive construction of the words "shall not be questioned" indicates an intent to inspire confidence in bond-holders that the government will take no action interfering with their debts. Third, the word "validity" implies that the government's obligation to ensure its credit extends over the entire time period during which debt obligations are being held. Fourth, the evolution of the Clause suggests that the Framers chose the Clause's words deliberately. The following subsections consider in turn these linguistic reasons for preferring the high generality level interpretation of "validity ... shall not be questioned."

\section{a. Meaning of "to Question"}

The verb "to question" would be an odd synonym for "to repudiate.” Questioning a proposition is not equivalent to insisting that the proposition is false but merely entails suggesting that it might be. To say, "I question whether your debt will be honored," is different from saying, "Your debt will not be honored." Analogously, to say that a statute must not question a debt's validity is different from saying that a statute must not repudiate a debt. ${ }^{103}$ Intuitively, the verb "to question" is much closer to the verb "to undermine" than it is to the alternative "to cancel." 104 Therefore, the

427 U.S. 273, 296 (1976) ("[T]he 39th Congress was intent upon establishing in the federal law a broader principle than would have been necessary simply to meet the particular and immediate plight of the newly freed Negro slaves."). The Framers not only did not limit $\S 1$ to a constitutionalization of the Civil Rights Act of 1866, but did not even limit the Equal Protection Clause to protecting blacks. Of course, this is hardly conclusive about $\S 4$. But it suggests that any reflex to assume that provisions were meant narrowly is particularly inappropriate in the context of a Fourteenth Amendment constitutional provision.

${ }^{103}$ For another analogy, consider Justice Brandeis's famous remark: "When the validity of an act of the Congress is drawn in question ... this Court will first ascertain whether a construction of the statute is fairly possible by which the question may be avoided." Ashwander v. Tennessee Valley Authority, 297 U.S. 288, 348 (Brandeis, J., concurring) (emphasis added). While the similarity in language to the Public Debt Clause is almost surely coincidental, this quotation helps reveal what it means to question something's validity. Justice Brandeis of course did not mean that a statute should be narrowly construed when a constitutional provision has made it unambiguously of no force; he meant that when it seemed there might be an issue of constitutionality, the Court would try to avoid that issue. Likewise, the Public Debt Clause is triggered not only when the government has made it absolutely clear through a failure to make payment that a debt will not be honored, but also when the government's actions effectively raise the issue.

${ }^{104}$ In addition, nothing in the verb "to question" makes it more like "to undermine intentionally" than like "to undermine inadvertently." True, the sentence "I question the debt," makes it sound like I am questioning the debt intentionally. But that is only because the verb has a subject. See infra note 107. By contrast, the phrase "the debt is now 
literal interpretation of the Clause is that a governmental action making uncertain whether or not a debt will be honored is unconstitutional. ${ }^{105}$

\section{b. Passive Construction}

The passive construction of the phrase "shall not be questioned" provides additional evidence about how the Framers conceptualized the Public Debt Clause and thus helps explain why the Framers used the word "questioned." The Framers were not fond of the passive voice; indeed, the Joint Committee voted to change a passive version of what became the second sentence of $\S 4$ to the active voice. ${ }^{106}$ Passive sentences are useful for authors who do not wish to restrict a verb to a particular subject. If the Framers meant only that the United States must not question the validity of its debts, they could have used the compact phrase, "The United States shall not question the validity of its public debt ...." While the Clause surely means at least this, it might also convey, "the validity of the public debt ... shall not be questioned by the people.”

The passive construction thus allows for a reading of the Clause as containing a reassuring promise from the Framers to bondholders. Moreover, the passive language makes the Clause more evocative than descriptive, more like an announcement of a general principle of debt validity than like a technical rule barring failure to make debt payments. It would be inconsistent with this promissory announcement and with the word "questioned" if a statute could cause bondholders to believe that their debts will not be paid as promised and that they will need to seek redress in the courts to recover belated payment. ${ }^{107}$

\section{c. The Word "Validity"}

A debt does not become valid or invalid only at the moment payment is due. A debt's validity may be assessed at any time, and a debt is valid only if the law provides that it will be honored. ${ }^{108}$ Therefore, a

questioned" does not imply that anyone intended the act that caused the questioning.

${ }^{105}$ A counterargument might charge that the Framers used the verb "to question" as a restrained way of saying "to repudiate." This is a weak counter, because its only impetus is an assumption that the Framers must have meant to preclude only direct repudiation, the meaning of the words of the Clause notwithstanding.

${ }^{106}$ See KENDRICK, supra note 18 , at 103.

${ }^{107}$ Conceiving of the Clause as containing a promise to debtholders also problematizes a reading of the Clause as prohibiting only congressional acts intentionally leading to nonpayment. Debtholders would care not about whether Congress meant to place their debts into question, but about whether they could count on receiving payment. If the Clause means that debtholders shall have no reason to question their debts - a meaning which the passive construction allows - then there is no reason to limit the Clause with an intentionality requirement.

${ }^{108}$ Among the legal definitions of "valid" is "sustainable and effective in law, as 
requirement that the government not question a debt's validity does not kick in only once the time comes for the government to make a payment on the debt. Rather, the duty not to question is a continuous one. If government actions make it so that a debt will not be paid absent future governmental action, that debt is effectively invalid. ${ }^{109}$ The intermediate level of generality recognizes that instead of referring to payment of debts, the Clause bans government action at any time that affects the validity of debt instruments.

The word "validity" indicates that not merely the existence of the public debt, but also its binding force on the government "shall not be questioned." 110 The government thus may not acknowledge that the public debt exists but refuse to pay it. If the government fails to make a debt payment, the debt instrument is at least temporarily invalid for legal purposes. ${ }^{111}$ Moreover, there is no such thing as a valid debt that will nonetheless not be honored; a debt cannot be called "valid" if existing laws will cause default on it. ${ }^{112}$ So as soon as Congress passes a statute that will lead to default in the absence of a change of course, the debt is invalid (or at least of questionable validity) and Congress has violated the Public Debt Clause.

distinguished from that which exists or took place in fact or appearance, but has not the requisites to enable it to be recognized and enforced by law.” BLACK's LAW DiCTIONARY 1440 (6th ed. 1990). None of the definitions of "valid" suggests that the attribute of validity exists only at the time of contract performance or debt payment. Therefore, government action may constitute validity questioning not only when the government fails to make a payment, but also when action brands a debt invalid.

${ }^{109}$ The Public Debt Clause does not distinguish debts that are invalid for all practical purposes from debts that the law explicitly brands as invalid. The word "validity" does not implicitly contain such a distinction, and it is not modified by the word "legal." Reading the distinction into the Clause would allow the government to pass one statute providing that debts shall be legally valid, but another providing that the Treasury must not make payment on them. This perverse definition of validity would allow an end-run around the Clause and would defy the Framers' intent to reassure debt-holders that their debts will be honored.

${ }^{110}$ In the absence of the words "validity of the," the Public Debt Clause might be viewed as establishing only a default rule. In other words, by pronouncing the legitimacy of "the public debt," this version of the Clause would mandate the repayment of debts, including those incurred in suppressing rebellion, unless a future Congress specified otherwise. Such a clause would preclude judges from holding that Congress was unauthorized to accumulate a public debt, but would not prevent future Congresses from repudiating their obligations.

${ }^{111}$ Thus a governmental delay in paying a debt violates the Clause. If the government refuses to make a payment on a debt at the time due but promises to make it later, the government has not maintained the validity of the debt. Rather, the government has effectively canceled the debt and substituted another one. While the government may well make good on its promise, but this compensation validates the later promise, not the original one.

${ }^{112} \mathrm{~A}$ debt may become invalid regardless of whether Congress intended to make it so. The Clause's focus on the validity of debts rather than on congressional action thus suggests that whether Congress intended for nonpayment to result is irrelevant. 


\section{d. Evolution of the Language}

The evolution of the Clause suggests that Congress's choice of language was not accidental. As discussed above, ${ }^{113}$ the final language of the Clause was close to the language of an earlier proposal, but it differed in that the phrase "validity ... shall not be questioned" was substituted for "shall be inviolable." The change suggests a conscious choice of "validity . . . shall not be questioned" over "inviolable," which is close to "unrepudiable."114 Why would the Framers shift to the word "questioned" if the original language was what they actually meant? At the least, the shift suggests a preference for phraseology that protects the public debt so strongly as to put the government's commitment to it beyond question. The only way to give effect to this preference is to interpret the Clause as precluding government action that makes default possible.

\section{Historical Evidence}

Three historical factors suggest that the Framers viewed the Clause not just as a ban on nonpayment, but rather as a more general expression of the government's commitment to ensuring the debt's validity. First, as argued above, ${ }^{115}$ imminent debt repudiation was extremely unlikely given $\S$ 3 of the Amendment, so there is no reason that the Framers would have been more concerned with the possibility that Congress would intentionally cancel debts than with the government's general duty to secure payment of its debts. Indeed, the Clause reflected the Framers' commitment to the sanctity of full faith and credit, ${ }^{116}$ and a purpose of the Clause was the securing of the nation's credit by guaranteeing payment to bondholders. ${ }^{117}$ Full investor confidence in the validity of the debt requires not just a constitutional nonpayment ban, but also a statutory regime that provides for payment. ${ }^{118}$

\footnotetext{
${ }^{113}$ See supra text accompanying note 31 .

${ }^{114}$ The difference between "inviolable" and "unrepudiable" is that the former makes clear that a partial invalidation of debt, such as a promise to pay back a bond but without interest, is impermissible. The phrase "the validity ... shall not be questioned," also appears to bar such violation, because a partial cancellation invalidates a debt obligation and replaces it with a lesser one.

${ }^{115}$ See supra text accompanying notes 48-55.

${ }^{116}$ See supra notes 43-47.

${ }^{117}$ See supra note 34.

${ }^{118}$ Even with constitutional protection, a statute providing for payment will boost investor confidence. See also infra note 181. Investors are more likely to perceive the Public Debt Clause as securing their debts if the Clause is applied to strike down statutes that would result in default. Even if debt-holders ultimately received payment, that payment would be delayed, the value of the debts would likely decline because of the initial repudiation, and the debt-holders would suffer litigation risk. In addition, if Congress were to engage in a course of action that would make it impossible (either practically or mathematically) for a successor
} 
Second, participants in the ratification debate did not conceptualize the Clause as being only a technical ban on the failure of the government to make debt payments. Both proponents and opponents of the Clause agreed that it precluded taxation of income from outstanding bonds. ${ }^{119}$ Such taxation would not trigger the intermediate level of generality, which bans only nonpayment, not actions occurring before or after scheduled payment that lower the value of debt. ${ }^{120}$ The debate suggests that the Clause was viewed as a general principle requiring the government to ensure the full and unconditional validity of debts.

Third, just a month before the final debate on the Fourteenth Amendment, Congress passed a statute converting the bulk of bond payments into a permanent appropriation. ${ }^{121}$ Thus, instead of leaving bondholders to the whims of future Congresses or the courts, Congress sought to place the public debt above the fray. ${ }^{122}$ Accepting the intermediate level of generality would mean that Congress could repeal this statute and substitute an annual appropriation. It would be odd if a constitutional limitation and a statute pursued the same goal of protecting government debt, but the constitutional provision would tolerate repeal of the statute and thus subversion of the goal.

\section{Identifying Debt Questionings}

While a repudiation rule offers the advantage of a simple enforcement test, it is also possible to create administrable tests for a prohibition on a broader class of debt questionings. A fact-finder could assess purported breaches of the Clause using either an objective or a subjective standard. ${ }^{123}$ The objective standard inquires into whether a

Congress to honor all of its debts, then the constitutional provision probably wouldn't work. The Supreme Court might refuse to apply the Public Debt Clause, or it might be repealed through Article $\mathrm{V}$ amendment.

${ }^{119}$ See, e.g., Joseph B. James, The Ratification of the Fourteenth Amendment 18, 224 (1984).

${ }^{120}$ The high level of generality probably does ban taxation of government bonds, at least at rates higher than those existing at the time of the bonds' purchase. A tax jeopardizes debts by providing that they will not be honored in full unless Congress repeals the tax after payment. However, the Sixteenth Amendment's allowance of income taxes arguably trumps the Public Debt Clause's prohibition of excess bond taxation.

${ }^{121}$ See supra note 54 . Routine appropriations were made on an annual basis. See, e.g., Act of Apr. 6, 1866, ch. 27, 14 Stat. 14 (providing miscellaneous appropriations).

${ }^{122}$ The statute may also reflect administrative simplicity, since Congress could know in advance when bonds would become due. However, in no meaningful sense is it more difficult for the government to budget expected payments during each budget cycle rather than in advance. What makes a permanent appropriation unique is that money will be spent unless Congress affirmatively repeals it. See, e.g., Charles Tiefer, "Budgetized" Health Entitlements and the Fiscal Constitution in Congress's 1995-1996 Budget Battle, 33 HARV. J. ON LEGIS. 411, 415-16 (1996) (contrasting annual and permanent appropriations).

${ }^{123}$ This section uses the terms "objective" and "subjective" to refer to whether a test 
governmental action in fact jeopardized debt, while the subjective standard asks whether holders of the public debt are genuinely concerned about the validity of their debts. These standards can be translated into bright-line rules. For example, a bright-line test of the objective standard might be whether the United States would meet its debt obligations if Congress never passed another statute (or passed only statutes adhering to long-term budget projections). ${ }^{124}$ Similarly, with bond debt, a bright-line test of the subjective standard might be whether any rating service had downgraded the debt. ${ }^{125}$ While it might seem odd for a constitutional test to depend on the actions of private agencies, this approach makes sense if the test's aim is to dermine whether debtholders are genuinely considered about government action. Just because the objective and subjective standards may be translated into these bright-line tests does not necessarily mean that these are the only possible tests. ${ }^{26}$ The point is that it need not be difficult to apply a test once selected, ${ }^{127}$ even if it is difficult to pick a test from among those possible. ${ }^{128}$

It is impossible to prove that the bright-line objective and subjective tests sketched above are the best tests or that one is better than the other. However, there are practical reasons to prefer these tests over others, and to prefer the objective over the subjective. An advantage of both tests is that although they take the word "questioned" seriously, they do not turn the word into a hair-trigger. A wide range of governmental actions presumably has marginal effects on both the probability of default and concern about the

considers debtholders' state of mind, not to whether a test may be administered without bias.

${ }^{124}$ For example, if Congress repealed a statute providing for repayment of a debt not yet due, thus leaving it to the discretion of a future Congress whether to honor the debt, the repeal would violate the objective test. See also supra note 96.

${ }^{125}$ Bright-line subjective tests for non-bond debt are more difficult, but not impossible, to develop. For example, a bright-line test of the solidity of government pensions might find a debt questioning if a given percentage of government employees began to purchase private insurance against the possibility of decreased payments.

${ }^{126}$ For example, an alternative test for the objective standard, also bright-line, would consider a warning by a ratings service to constitute a debt questioning. The subjective standard could be assessed using a multi-factorial test, in which a judicial fact-finder might consider bond ratings, stock and bond prices, statistical studies, newspaper commentary, and testimony by debt-holders. Or a court might create a balancing test that allowed limited questionings where the government had substantial or compelling interests.

${ }^{127}$ Even if the best test required a judge to make an intuitive finding about whether a debt questioning had occurred, such a judgment might still be superior to a rule narrowing debt questioning to repudiation. Judicial tests for violations of the Fourteenth Amendment, such as the intermediate scrutiny Equal Protection Clause test for quasi-suspect classifications, are often difficult to apply but are applied nonetheless. See, e.g., Mississippi University for Women v. Hogan, 458 U.S. 718, 742-44 (Powell, J., dissenting) (disagreeing with Court's conclusion under intermediate-scrutiny test).

${ }^{128}$ The difficulty in picking appropriate tests has, of course, not led the courts to assume that other provisions of the Fourteenth Amendment should be applied as narrowly as possible. Rather, the judiciary actively debates what are appropriate tests for violation, for example, of the Equal Protection Clause. See, e.g., id. at 724 n.9 (O’Connor, J.) (confronting objections to intermediate-scrutiny test). 
possibility of such default, but to conclude that all of these actions violate the Clause would stifle too much activity. ${ }^{129}$ Just because "questioned" is roughly synonymous with "jeopardized" does not provide a textual argument that any statute increasing the probability of repudiation even marginally should be held to constitute a debt questioning. Just because this Article has concluded that "to question" most closely means "to jeopardize" does not mean that it must conclude that "to question" means "to jeopardize even just a little bit." "To question" might also mean "to jeopardize somewhat" or "to jeopardize a lot".

Because nothing in the phrase "shall not be questioned" indicates to what degree jeopardization must occur before it will constitute a questioning, it makes sense for tests of questioning to take a balanced approach. On the one hand, a test should not brand as unconstitutional government actions that have very small effects on debt accumulation, but that Tests can recognize this by identifying only substantial increases in the probability of repudiation or in debt-holders' concern about it. The objective test accordingly finds a questioning only when the existing statutory scheme would in fact lead to default in the absence of further congressional action. Similarly, the subjective test triggers the Clause only when a bond agency lowers the rating of U.S. debt because its riskiness passes a substantial threshold. ${ }^{130}$

The objective and subjective tests reflect different purposes of the Clause and the different plausible subjects of the past participle "questioned." Essentially, the objective test identifies a questioning by the government and thus is compatible with an interpretation of the Clause as banning any congressional or judicial action making a debt's repayment uncertain. The subjective test reflects the reassurance component of the Clause and asks whether the people have genuine concerns about the government's actions. The objective standard may therefore be preferable, because the Clause achieves its goal of reassuring debt-holders through its central mechanism, a limit on governmental action. ${ }^{131}$

\footnotetext{
${ }^{129}$ For example, any increase in debt presumably raises the probability that the government will be unable to meet existing debts. But a rule preventing the government from issuing any new debts would clearly sweep too far and, indeed, defeat a purpose of the Public Debt Clause, the securitization of the nation's debt issuance.

${ }^{130}$ Relying on bond ratings rather than bond prices is essential. If the test targeted a decline in bond prices, it would inappropriately assume that investor jitters were a proxy for the probability of default. Bond prices reflect not only the probability of default but also changes in the time value of money and the availability of alternative investments. Bond ratings, however, reflect only those jitters caused by perceptions of an increased probability of default.

${ }^{131}$ However, one could argue that either test alone or both tests together should identify a debt questioning for the Clause to be triggered. If the Public Debt Clause is seen as protecting against only those governmental actions threatening repudiation and worrying debt-holders, then both tests should be necessary conditions for triggering the Clause. In contrast, if the Clause is seen as protecting against only the possibility of repudiation or
} 


\section{C. $\quad$ Outer Reaches of the Clause's Meaning}

In sum, reading the Public Debt Clause literally leads to a construction of the Clause that is broad in two senses. First, the "public debt" includes statutorily authorized congressional budgetary promises besides financial bond instruments. Second, governmental actions short of direct repudiation may trigger the Clause if they endanger the validity of debts. This broad construction may not be the only plausible interpretation of the Clause; the Framers might have intended something much narrower but drafted the provision carelessly. The point is, however, that a broad judicial construction of the Clause would not be tantamount to implicit constitutional amendment in defiance of an obvious limited meaning of the Fourteenth Amendment's words. Rather, such a broad construction would reflect a literal and sensible interpretation of the Clause's words.

This Article's interpretation of the Public Debt Clause hardly exhausts questions about the Clause's substantive limits. ${ }^{132}$ For example, does the Clause encompass debts that the government incurs through compulsion, or only those in which the government's promise serves as an incentive in the open market for assumption of government debts? ${ }^{133}$ May Congress make a promise that would ordinarily become part of the public debt, but reserve to itself the right to change or renege on its promise? ${ }^{134}$ Does the Public Debt Clause encompass all debts, or only those that the Congress explicitly makes on the credit of the United States or pursuant to the Clause itself? ${ }^{135}$

against only concern about repudiation, then the single appropriate test should be sufficient.

${ }^{132}$ Equally difficult are questions about the Clause's procedural limits; what happens when Congress appears to violate the Public Debt Clause? Some of these questions are addressed in Part IV, infra, which asks to what extent constitutional infirmities in budget processes and policies are justiciable.

${ }^{133}$ For example, one might argue that if the government were to require all Americans to buy $\$ 500$ bonds, those bonds would not implicate the Public Debt Clause. Because the government could have simply compelled purchase without exchanging a promise, it has not taken advantage of the credibility that the Public Debt Clause provides. This argument, however, may at odds with a central purpose of the Clause: assuring the public that greenbacks, which the Legal Tender Acts forced on government contractors, would remain valid. See supra text accompanying notes 43-46. On the other hand, government contractors retained the option of leaving the market altogether.

${ }^{134}$ Suppose, for example, that the Congress issued bonds with a maturity value of $\$ 500$, but provided in the bonds' terms that Congress shall pay on maturity $\$ 500$, or such other amount as it might subsequently decree by law. Although the bondholder recognizes ex ante that the bond's value is subject to Congressional discretion, one might argue that the Public Debt Clause precludes the government from issuing non-full faith debt or, more generally, reserving to itself the right to renege on its promises. On the other hand, if one accepts the principle that the government may reserve to itself the unilateral right to modify promises, one might further argue that such a reservation is inherent in the legislative power itself.

${ }^{135} \mathrm{~A}$ rule that Congress incurs a debt only by specific reference to the Clause would be tantamount to a default rule treating Congressional promises as retractable. Such a default rule might be a sensible bright-line rule if recipients of governmental promises ordinarily 
These questions are difficult both interpretively and normatively. Nothing in the history or language of the Clause indicates to what extent Congress may control whether a given transaction implicates the Clause. Allowing Congress to withhold full-faith status from obligations seems counter to the nature of a constitutional provision limiting congressional power and discretion. On the other hand, robotically tossing all congressional promises into the public debt leaves open the possibility that Congress might use the Public Debt Clause as a constitutional trick to impose its substantive budgetary preferences on future Congresses. There are sensible middle-ground positions; for example, the Clause might be interpreted as binding whenever Congress makes an unqualified promise and could reasonably have believed that binding itself would be beneficial. This Article assumes that the courts could place appropriate limits on the Public Debt Clause, ${ }^{136}$ and Part II attempts to distinguish situations in which the Clause's applicability depends on the broad construction that this Section defends or on particular additional assumptions about the Clause's limits.

\section{Applications of the Public Debt Clause}

This Part describes how application of the Public Debt Clause could reform congressional budget process problems that threaten fiscal disaster along various time horizons. Section III.A shows how the Clause could limit the destructive potential of budget impasses in the short term. Turning to long-term problems, Section III.B explains how the Clause could diminish accumulation of debts, while Section III.C assesses whether the Clause protects the entitlements that contribute to the debt. This organization also tracks movement from budgetary issues that the Clause almost certainly affects to areas in which the Clause's relevance is less certain.

\section{A. $\quad$ Train Wrecks}

Congressional budget impasses introduce the specter of "train wrecks." 137 The metaphor goes like this: When Congress and the President fail to agree on a budget by the beginning of the fiscal year, the previously

realize that the government is likely to renege. The counterargument, of course, would be that the point of the Public Debt Clause is to instill confidence in the reliability of government promises.

${ }^{136}$ Any jurisprudential rules limiting the Clause's applicability would need to clarify first, how unequivocally Congress must act in making a promise for it to become part of the public debt, and second, what showing Congress must make to establish that the promise reflects a genuine debt rather than a substantive value preference. The broadest possible interpretation of the Clause would place any congressional promise into the debt without examining Congress's motives.

${ }^{137}$ See Michael Wines, The Budget: A Train Wreck?, N.Y. TiMEs, June 18, 1995, at 22. 
smooth-running government train begins to derail, with non-essential services ${ }^{138}$ pushed along only if Congress and the President can agree on "continuing resolutions." 139 The train continues to edge forward until the government both runs out of cash and reaches the federal limit on borrowing. Then, the government train crashes and stops, a wreck that only a subsequent infusion of cash or a suspension of the debt limit can budge.

No budget impasse has ever led to a train wreck, but it has come close, most recently and precariously at the start of the 1996 fiscal year, ${ }^{140}$ when the inability of Congress and the President to agree on a budget or a debt-limit increase threatened default. ${ }^{141}$ The government shut down nonessential services, but temporary waivers of the federal debt limit ${ }^{142}$ and accounting tricks by the Treasury ${ }^{143}$ kept the government from reaching the limit. ${ }^{144}$ Although the Congressional Budget Office has recommended abolition of the federal debt limit, ${ }^{145}$ Congress has not responded. The

${ }^{138}$ Non-essential services are those not "involving the safety of human life or the protection of property.” 13 U.S.C. § 1342 (1996).

${ }^{139}$ See, e.g., Act of Nov. 20, 1995, Pub. L. No. 104-56, 109 Stat. 548 (allowing temporary funding of some federal government programs).

${ }^{140}$ An earlier debt-ceiling crisis occurred in 1985. See, e.g., Alan Murray, Treasury Says U.S. Will Default Friday Without Debt Bill, WALl ST. J., Nov. 13, 1985, at A1.

${ }^{141}$ See, e.g., Leon Hadar, US Default on Debt? Oh Yes, It Can Happen, Business TIMES, Jan. 19, 1996, at 10; Alan Murray, Debt-Limit Crisis Is Not Over Yet, WALl ST. J., Nov. 27, 1995, at A1.

${ }^{142}$ See, e.g., Act of Feb. 8, 1996, Pub. L. No. 104-103, 110 Stat. 55 (exempting amount equivalent to one month of Social Security payments from being counted toward debt ceiling); Act of March 12, 1996, Pub. L. No. 104-115, 110 Stat. 825.(exempting government trust fund investments and reinvestments from debt ceiling).

${ }^{143}$ Treasury Secretary Rubin took advantage of statutory changes passed in the wake of the 1985 debt-ceiling crisis designed to help avert default. See Omnibus Budget Reconciliation Act of 1986, Pub. L. No. 99-509, Title VI, sec. 6002(a)-(c), 100 Stat. 1874, 1931. The changes authorized him to redirect investments in pensions funds, 5 U.S.C. $\S 8348(j)(1)$ (1996), and "to sell or redeem securities, obligations, or other invested assets of the Fund before maturity in order to prevent the public debt of the United States from exceeding the public debt limit,” $\S 8348(\mathrm{k})(1)$. The Secretary may take these actions only during a "debt issuance suspension period," defined in $\S 8348(\mathrm{j})(5)(B)$ as "any period for which the Secretary of the Treasury determines . . . that the issuance of obligations of the United States may not be made without exceeding the public debt limit.” The General Accounting Office later determined that the Treasury's actions were authorized by the statute. See GENERAL Accounting OfFice, Debt CeILING--Analysis of Actions DuRing the 1995-1996 Crisis (1996); Clay Chandler, GAO Says Rubin Tapped Retirement Funds Legally, WASH. Post, Sept. 7, 1996, at D2. Republicans have charged, however, that Secretary Rubin exceeded his legal authority. See Nick SMith, Report of THE House TASK ForCE ON THE DEBT Limit AND Misuse OF THE TRUST FundS (1996) (questioning Secretary's authority to declare debt issuance suspension period); Constitutional Debt Crisis, ST. Louis PosT-DisPatch, Jan. 12, 1996, at 15C (noting statements of former Attorneys General and Treasury Secretaries warning of illegality of Treasury Secretary Rubin's plans).

${ }^{144}$ See Contract with America Advancement Act of 1996, Pub. L. No. 104-121, sec. 301, 110 Stat. 847 (resolving crisis by raising debt ceiling).

${ }^{145}$ See Congressional Budget OfFice, The Economic And Budget OutlooK: An Update 48, 54 (1995). The General Accounting Office has long favored elimination of the statutory 
possibility of a future train wreck thus raises two questions: First, is it constitutional under the Public Debt Clause for the government to stop payments on bonds and other obligations? And second, is the debt-limit statute that makes a train wreck possible itself constitutional?

\section{Governmental Failure to Make Payments on Bonds}

If the debt were to reach the statutory ceiling, ${ }^{146}$ the Treasury might fail to make a required interest payments on its bonds. ${ }^{147}$ Such a failure would transcend mere questioning of the public debt's validity; it would constitute partial invalidation of the public debt, because the Treasury commits in its regulations to make interest payments at certain times. ${ }^{148}$ Such partial invalidation runs afoul of the Public Debt Clause for two reasons. ${ }^{149}$ First, a "partial-faith-and-credit" principle would allow the government to liquidate its debts for nominal consideration and convert the Clause into a virtual nullity. Second, a delay in payment calls into question the government's commitment to pay the remainder of a debt and its commitment to pay other debts, thus violating the proviso that the debt's validity "not be questioned." 150

Assuming that the government must pay damages for a breach of the Public Debt Clause, what is the measure of damages? ${ }^{151}$ Because bond

debt limit. See General Accounting Office, A New Approach to the Public Debt LEgislation SHOUld Be Considered (1979). Bills accomplishing a repeal were considered in the last Congress. See, e.g., H.R. 215, 104th Cong. (1995).

${ }^{146}$ The debt limit is set in 31 U.S.C.A. § 3101 (Westlaw 1996), which currently provides that "[t]he face amount of obligations ... whose principal and interest are guaranteed by the United States Government (except guaranteed obligations held by the Secretary of the Treasury) may not be more than $\$ 5,500,000,000,000$ outstanding at any one time ...." For a comprehensive history of $\S 3101$, see DEPARTMENT OF THE TREASURY, Budget of THE United States Government, Fiscal year 1996, Historical Tables 92-94 (1995) [hereinafter HistORICAL TABLES].

${ }^{147}$ The United States has failed to make timely payments before, most recently in 1979, when despite the resolution of a debt-limit crisis, administrative snafus at the Treasury Department led to delayed payments on some bond issues. See James J. Angel, Looking Back at Debt Defaults in U.S. History, CHI. TRIB., Feb. 1, 1996, at 21 (arguing that default "would have serious consequences, but ... would not be the end of the world").

${ }^{148}$ See 31 U.S.C. § 3121(a)(5) (1996) (authorizing Treasury to specify dates on which it will pay bonds' principal and interest).

${ }^{149}$ At least two newspaper editorials have suggested that default on the debt would be unconstitutional. See Steve Charnovitz, Extortion and the Debt Ceiling, J. CoMmERCE, Nov. 16, 1995, at 10A; George B. Tindall, Is This Train Wreck Constitutional?, News \& OBSERVER (RALEIGH), Nov. 15, 1995, at A25.

${ }^{150}$ Even the possibility of a partial repudiation caused investors to lose some faith in U.S. bonds. See David E. Sanger, S.\&P. Strongly Warns U.S. on the Danger of Default, N.Y. TiMES, Nov. 11, 1995, at 37 (reporting that faith of investors in government debt had been diminished, despite Standard \& Poor's decision not to lower United States's AAA credit rating).

${ }^{151}$ Just because the United States would presumably need to pay damages for failing to honor 
markets are highly competitive, a bondholder presumably could have purchased a perfect substitute for a U.S. bond, so the bondholder's damages are the same using either an expectancy or a reliance formulation. ${ }^{152}$ Under either scheme, the government would owe not just the missed interest payment, but also interest on that payment that would have accumulated during litigation. Even these damages might not fully compensate bondholders, however, since the debt repudiation would hurt the United States's credit rating and thus lower the value of outstanding bonds. ${ }^{153}$

\section{Non-Bond Obligations Within the Public Debt}

The government's reaching the debt ceiling would stop not just interest payments on bonds, but also other government obligations. Unless the Public Debt Clause applies only to debts explicitly made on the credit of the United States, ceasing payments for some of these obligations would also raise constitutional questions. Indeed, such a cessation would be problematic not only if it occurred because of a debt-ceiling crash, but also if Congress and the President failed to reach a budget agreement and the government shut down, as in 1995-96.

Determining which government payments are discretionary and which are required under the Public Debt Clause may be difficult in some instances, but some ordinary government expenditures fit squarely within the broad construction of the public debt defended in Part II. For example,

a debt does not mean that it is constitutional for the United States not to honor a debt, as long as it pays later. In other words, there is no reason to import into the Public Debt Clause the limited, Holmesian view of contractual obligation: "The only universal consequence of a legally binding promise is, that the law makes the promisor pay damages if the promised event does not come to pass.” Oliver Wendell Holmes, The Common LAW 301 (1881). The Public Debt Clause changes the promisor's ordinary choice by requiring the United States to meet its fiscal commitments. For the Clause to have any enforceability, the courts will need to be able to impose damages if the United States fails in its constitutional duty, but this does not mean that the government has taken a constitutionally permissible step by failing to make a debt payment. Nonetheless, there is something anomalous about enforcing a constitutional requirement that the government keep promises by allowing the government to break promises and then pay damages. The cure in the case of the budget impasses is for the courts to strike down the debt-limit statute that makes default possible, as explained below.

${ }^{152}$ See, e.g., E. Allan Farnsworth, Precontractual Liability and Preliminary Agreements: Fair Dealing and Failed Negotiations, 87 ColuM. L. REV. 217, 225 n.20 (1987) (noting conditions for merger of expectancy and reliance damages).

${ }^{153}$ Computing such damages would be difficult, because a court decision reimbursing a bondholder would reinstill confidence in U.S. bonds and cause them to appreciate. It is possible that the bonds would rise to even greater than their initial value, since such a decision could reassure bondholders about the vitality of the Public Debt Clause and make uncompensated repudiation seem even less likely than initially. On the other hand, bondholders might not have confidence in the precedential value of the court decision, and the willingness of the government to default might overshadow the willingness of the court to order compensation. In addition, any uncompensated litigation costs incurred in defending bonds adds to the cost of their ownership. 
government civil-service pension payments and money owed to independent contractors represent unambiguous obligations that the government owes because of past agreements in which the debt-holders have already fulfilled their part of the bargains.

There are gray areas in which recipients of government money have an expectation of continued receipt but in which there may or may not be an agreement triggering the Public Debt Clause. If the Public Debt Clause applies to obligations that the government requires individuals to purchase, a budget crisis might not relieve the government of its duty to issue Social Security checks, since it has promised to make payments from a trust fund accumulated in part through recipients' own contributions. ${ }^{154}$ A failure by the government to make a payment because of a train wreck would breach a statutorily established agreement that the government will provide beneficiaries means of subsistence in exchange for their earlier contributions. $^{155}$ Medicare is less likely to qualify as a government agreement with beneficiaries, because there is less of a nexus between an individual's contributions and benefits than in the case of Social Security. ${ }^{156}$

Similarly, current government employees expect to be paid, but they are subject to dismissal, ${ }^{157}$ and the annual budget process serves as an implicit annual review of which employees' contracts to renew. Whether the government would need to make salary payments depends on whether the government incurs a public debt when it hires an employee or when the employee has actually performed contracted-for duties. This hinges in turn on whether the government is considered to have formed agreements of continued employment with its employees.

\section{The Federal Debt-Limit Statute}

Regardless of which governmental obligations are part of the public debt and thus unconstitutional to repudiate, the federal debt-limit statute makes train wrecks and thus repudiation possible. Although the debt-limit statute is theoretically written in pursuance of the goals of the Public Debt

\footnotetext{
${ }^{154}$ See Social Security Act of 1935, 49 Stat. 622 (principally codified as amended at 42 U.S.C. §§ 401-433 (1996)).

${ }^{155}$ The counterargument is that the government has not entered into agreements with beneficiaries, but rather has established a statutory scheme that it can change. See infra Section III.C. Even if the government has reserved the right to alter Social Security in general, however, a beneficiary might claim that the government must continue to make payments until it changes the statutory scheme to discontinue them.

${ }^{156}$ Medicare is a hybrid system. Part A of Medicare, providing hospital insurance, is funded like Social Security, through a special payroll tax that accumulates in a trust fund. Part B, offering supplemental medical insurance, is funded primarily through general tax revenues. See, e.g., Tiefer, supra note 122, at 417.

${ }^{157}$ Cf. Crenshew v. United States, 134 U.S. 99 (1890) (holding that government employee has no contractual right against termination by Congress on public-policy grounds).
} 
Clause, ${ }^{158}$ it works counter to the Clause's goals. The statute precludes government borrowing above a level that Congress has set, even if that borrowing is needed to meet expenses required to maintain the public debt's validity. The statute thus works at cross-purposes, serving both as a legitimate exercise of federal power under the Public Debt Clause ${ }^{159}$ and as a potential cause of unconstitutional debt repudiation. Whether the statute in fact increases or decreases the probability of default or investor confidence is therefore impossible to determine a priori. ${ }^{160}$ Under the objective and subjective tests for debt repudiation defended above, ${ }^{161}$ however, it is not necessary to weigh these effects speculatively, ${ }^{162}$ and the statute flunks at least the objective test and possibly the subjective test also.

The Public Debt Clause promises bondholders not just that bonds will remain valid, but that their validity will not be questioned. ${ }^{163}$ The debt limit will necessarily lead to the repudiation of governmental obligations in the absence of congressional action, as the statutory scheme leaves open to question whether a later Congress will honor the public debt by changing the laws. The debt ceiling thus fails the objective test for debt questioning. Even if the Clause allowed one Congress to count on a future Congress to pay required debts, the debt limit statute is still suspect, because in the absence of the statute, repayment would necessarily occur. ${ }^{164}$ The debt limit thus takes an affirmative step toward repudiation and places into question Congress's commitment elsewhere expressed to pay the debt.

In addition, the statute functionally has allowed Congress to play chicken in Washington fiscal negotiations; ${ }^{165}$ Congress runs the budget train

\footnotetext{
${ }^{158}$ Indeed, the drafters of the proposed Balanced Budget Amendment effectively sought to constitutionalize the debt-limit statute by requiring a three-fifths majority of both Houses to raise the debt limit. See S.J. Res. 1, § 2 (1995). But see Seto, supra note 10, at 1516-19 (criticizing this enforcement mechanism).

${ }^{159}$ Combining Sections 4 and 5 of the Fourteenth Amendment gives Congress the power to legislate to ensure the validity of the public debt. See also infra Subsection III.B.2.

${ }^{160}$ The empirical question is whether the statute, by reflecting a congressional commitment not to let the debt rise above a certain level, inspires confidence in U.S. bonds that makes up for the chance of repudiation in the event of a train wreck. Because the debt limit has so far failed to stem long-term debt growth but has come close to bringing a train wreck, it seems intuitively likely that the statute decreases confidence.

${ }^{161}$ See supra Subsection II.B.4.

${ }^{162}$ That the tests do not require such a weighing makes sense in this context for two reasons. First, the tests are bright-line rules and thus designed not to entail abstract balancing. Second, Congress could exempt payments on the debt from the statute and thus preserve its debtensuring effects.

${ }^{163}$ See supra Section II.B. Under this Article's interpretation of "validity . . . shall not be questioned," the debt-limit statute may be attacked on its face and not merely only when it leads to repudiation of a debt in a particular circumstance.

${ }^{164} C f$. 31 U.S.C. § 3123(a) (pledging faith of United States in paying its bond obligations).

${ }^{165}$ See, e.g., Adam Clymer, G.O.P. Lawmakers Offer to Abandon Debt-Limit Threat, N.Y. TIMES, Jan. 25, 1996, at A1 (describing Republicans' offer to raise debt limit in exchange for “down payment” on balanced budget).
} 
directly toward the debt limit, hoping to force the President to make the turn that Congress prefers. ${ }^{166}$ If this abuse of the public-debt statute causes bondholders to question the validity of their debts, the Clause might be breached under a subjective test of its meaning, ${ }^{167}$ even if no default occurs. In addition, this abuse of the debt-limit statute militates against a conclusion that Congress's intent in the statue is genuinely to protect the validity of the debt.

As long as tax receipts are greater than public debt payments, a prioritization of public debt payments over other expenses could harmonize a debt-limit statute with the Public Debt Clause. The statutory scheme does not currently allow for such preferential treatment; the Treasury pays obligations on a rolling basis. ${ }^{168}$ When the public-debt ceiling has been reached, the Treasury makes a payment only if it has sufficient governmental receipts to do so. Government receipts arrive sporadically throughout the tax year, ${ }^{169}$ and a lump sum of receipts might be depleted by non-public debt expenses just before a debt payment becomes due. Therefore even with a budget in balance or surplus, the government might temporarily hit the debt ceiling in the middle of the year and fail to make needed expenses. It is theoretically possible that the timing of receipts and expenses would work out such that this would not occur, but nothing in federal budget practice guarantees this.

A debt-limit statute aimed only at ensuring the validity of the public debt would exempt borrowing for payments on the debt. In the absence of such amendment, it is difficult to imagine a modification, either judicially or congressionally imposed, that could save the debt-limit statute's constitutionality. A statute might allow the Treasury Secretary to anticipate the possibility of a debt-ceiling crisis and stop non-debt expenses to save for impending debt payments. The Treasury Secretary, however, might fail to anticipate a debt-ceiling crisis ${ }^{170}$ or might underestimate its duration. Thus,

\footnotetext{
${ }^{166}$ In theory, the game might flip, with the executive branch refusing to approve an increase in the public debt limit unless the legislative branch caves in to budget demands. Congress, however, has rigged the game by providing in 31 U.S.C. $\S 3101$ that the House can unilaterally raise the debt ceiling as necessary under its House Rule XLIX, also known as the Gephardt Rule. This rigging further undermines the claim that the debt ceiling's goal is to preserve the validity of the debt.

${ }^{167}$ See supra text accompanying note 125 . Under the subjective test proposed, the Clause would not have been breached since the debt was not downgraded. However, under a different formulation of the test, for example considering any investor skittishness sufficient to trigger the Clause, the Clause might have been violated.

${ }^{168}$ Under 31 U.S.C. § 3102 (1996), the Treasury Secretary may issue bonds to cover expenses as they become due.

${ }^{169}$ In December, 1995, for example, a sudden infusion of quarterly estimated tax payments helped keep the government briefly afloat. See GenERAL Accounting OfFice, supra note 143 , at 24-25.

${ }^{170}$ Indeed, existing law already gives the Secretary authority to declare a debt issuance suspension period and take certain defensive actions. See supra note 143. But like politics
} 
unless the Secretary ultimately has the authority to borrow to make payments on the public debt, the debt-limit statute leaves open the possibility of default and violates the Public Debt Clause.

\section{B. Deficits and Debt}

To read the Public Debt Clause as requiring a balanced budget would be a remarkable feat of interpretive legerdemain. After all, the Framers of the Fourteenth Amendment had just accumulated massive deficits and certainly were not promising never to do so again. Additionally, economists agree that a budget deficit of zero is a convenient but arbitrary target, ${ }^{171}$ so it can hardly be read into the Public Debt Clause's text. However, just because the Clause is not a Balanced Budget Amendment in disguise does not mean that it cannot serve as a substitute for such an amendment. If the accumulation of deficits makes questionable the government's ability to meet existing debt obligations, then the Clause may be triggered.

\section{Unsustainable Debt Accumulation}

The U.S. debt today is relatively small, ${ }^{172}$ and American bonds are considered among the "world's safest investments."173 Economists warn, however, that if the United States fails to increase taxes or reduce spending, the debt will spiral to unprecedented levels. ${ }^{174}$ Indeed, without change, the debt would increase faster than the growth of the economy itself. Economists define such growth as unsustainable, ${ }^{175}$ since if it remained unchecked, payments on the debt would ultimately consume the nation's entire economic output. Of course, at some point Stein's Law will become

generally, debt-ceiling crises can be unpredictable.

${ }^{171}$ See, e.g., William R. KeEch, Economic Politics 123 (1995) (“A nominal balance of the government's revenues and expenditures is a thoroughly arbitrary target, although it is very appealing politically because it is simpler than any other target and thus is more widely understood among voters.”).

${ }^{172}$ The debt held by the public at the end of fiscal year 1996 is projected at $52.1 \%$ of GDP; in other words, the debt is only about half one-year's national income. See HISTORICAL TABLES, supra note 146, at 90. The United States's structural budget deficit is smaller than that of all but two other OECD industrialized countries. See CONGRESSIONAL Budget OfFICE, supra note 5, at 90. For a review of the causes of large debts in OECD countries, see AlBERTO Alesina \& Roberto Perotti, The Political Economy of Budget Deficits (International Monetary Fund Working Paper No. WP/94/85, Aug. 1994).

${ }^{173}$ See, e.g., Financial Markets, L.A. TIMES, Jan. 25, 1996, at D3 (noting that U.S. bonds retain highest possible ratings).

${ }^{174}$ The Congressional Budget Office projects that under current policies, the debt-to-GDP ratio will climb to $311 \%$ by 2050 . See CONGRESSIONAL BudGET OfFICE, supra note 5, at 77.

${ }^{175}$ See id. at xxiii ("For a path of spending and revenues to be sustainable, the resulting debt must eventually grow no faster than the economy.”). 
operative: "If something cannot go on forever, it will stop." 176 The question is whether it will stop before a crisis of confidence in U.S. debt, after such a crisis but before repudiation, or after national insolvency. ${ }^{177}$ Most of the United States's debt is internally held, ${ }^{178}$ so a political constituency would oppose any effort at debt repudiation. If this Article is correct, such an effort would require a constitutional amendment, ${ }^{179}$ so even a minority might thwart it. But some have credited massive debt levels with bringing about the French and Russian Revolutions, ${ }^{180}$ and a true debt crisis could force the government to cut social services and bring unpredictable unrest.

The Public Debt Clause's "shall not be questioned" language allows the courts to intervene before debt repudiation becomes a viable option. ${ }^{181}$ The quandary, however, is in the line-drawing. Whenever the United States runs a deficit, it moves closer to an unmanageable debt level, but applying a hair-trigger test to debt accumulation would inflate the Public Debt Clause into a full-scale Balanced Budget Amendment. But if this approach would apply the Clause too soon, then waiting for debt repudiation applies it too late.

Both the objective and subjective tests of debt questioning 182 provide ways to apply the Clause in between these extremes. The subjective standard would be triggered when debt accumulation becomes so excessive that bond rating agencies downgrade U.S. debt. The objective standard would preclude any budget that would cause the debt to cross the economic

${ }^{176}$ See, e.g., Herbert Stein, Leave the Trade Deficit Alone, Wall St. J., Mar. 11, 1987, at A20.

${ }^{177}$ In a technical sense, governments cannot go bankrupt, since bankruptcy proceedings do not apply to the federal government. Moreover, the government can always whittle the debt down through inflation, except to the extent the debt is held in inflation-indexed bonds. See John R. Wilke, Treasury Plans to Sell Inflation-Indexed Bonds, WALL ST. J., May 16, 1996, at C1 (noting first planned Treasury issue of bonds protected against inflation).

${ }^{178}$ Approximately 20 percent of the national debt is held by foreigners. See ANALYTICAL PeRSPECTIVEs, supra note 82, at 195-96.

${ }^{179}$ One could argue that the Public Debt Clause is unrepealable. If repeal were proposed in a national crisis, the debt would unconstitutionally be in question after repeal seemed viable but before ratification by the states. However, Article V's strong presumption of amendability probably means the Framers of the Fourteenth Amendment did not intend to make an exception to Article V.

${ }^{180}$ See Seto, supra note 10 , at 1459 \& nn.24-25.

${ }^{181}$ This suggests a paradox: If the Supreme Court held debt accumulation to constitute a questioning, then presumably it would also hold repudiation illegal, but that precedent would mean that debt accumulation could not constitutionally lead to repudiation, and thus the accumulation ought not constitute a questioning. A resolution to this paradox views the government's actions independent of the Public Debt Clause's constitutional restraint. This is the only way to honor the Clause's "shall not be questioned" language. Moreover, Article V permits repeal of constitutional provisions, so fiscal unsustainability puts into question the validity of the public debt by making repeal seem like a viable option. Even without Article $\mathrm{V}$, the Supreme Court might in a national crisis overrule precedent and allow debt repudiation.

${ }^{182}$ See supra Subsection II.B.4. 
threshold of unsustainability. ${ }^{183}$ A deficit hawk might seek earlier application of the objective test by noting that the statutory scheme places the economy on the way to unsustainability. Such an anticipatory thrust is two levels removed from actual default, but there is no compelling counterargument to this expansive interpretation of "shall not be questioned." 184 In addition, it makes normative sense to deal with problems sooner rather than later, ${ }^{185}$ and it therefore might be healthy for the courts to ask Congress to clarify its long-term goals.

\section{Legislation Forcing Deficit Reduction}

Although Congress just missed the supermajority needed to pass the Balanced Budget Amendment, ${ }^{186}$ congressional support for a scheme that would tie Congress's hands and force budget balance has long been strong. Indeed, with the Balanced Budget and Emergency Deficit Control Act of $1985,{ }^{187}$ popularly known as Gramm-Rudman-Hollings, Congress attempted to create a statutory regime that would force budget balance by requiring the Comptroller General to implement an across-the-board cut, known as a sequestration, of non-entitlement expenditures to achieve balance if Congress failed to reach balance on its own. ${ }^{188}$ Although the Supreme Court found the Comptroller General's role in this scheme unconstitutional in Bowsher v. Synar, 189 Congress cured the statute's constitutional infirmities. ${ }^{190}$ Deficits continued to climb, however, as Congress and the Office of Management and Budget took advantage of accounting

\footnotetext{
${ }^{183}$ Application of such a standard would require a determination of whether interest payments on the debt are increasing at a faster rate than the economy will grow. Predictions of economic growth are uncertain, but given governmental economic statistics, this standard should be easy to apply. The statistics might in fact be inaccurate, but by mapping an isomorphism from the unquestionable validity of the public debt to its sustainability, the standard allows for dispassionate, bright-line assessment.

${ }^{184}$ Whether a budget on the path to unsustainability fails the objective test depends on whether the test asks what would happen if Congress passes no further statutes or what would happen if Congress sticks to its long-term plans.

${ }^{185}$ See, e.g., Congressional Budget Office, Reducing the Deficit: Spending AND REVENUE OptIONS 450 (1996) (arguing for addressing spending growth before retirement of baby boomers).

${ }^{186}$ See supra note 10.

${ }^{187}$ Pub. L. No. 99-177, 99 Stat. 1037 (codified as amended in scattered sections of 2, 31 \& 42 U.S.C.).

${ }^{188}$ See generally Kate Stith, Rewriting the Fiscal Constitution: The Case of Gramm-RudmanHollings, 76 CALIF. L. REV. 593 (1988).

${ }^{189} 478$ U.S. 714 (1986). The Court held that because Congress reserved the right to remove the Comptroller General, Gramm-Rudman-Hollings violated separations-of-powers principles by giving Congress a role in the execution of the laws. Id. at 736.

${ }^{190}$ See The Balanced Budget and Emergency Deficit Control Reaffirmation Act of 1987, Pub. L. No. 100-119, tit. I-II, 101 Stat. 754 (1987).
} 
loopholes, ${ }^{191}$ and ultimately Congress gave up on the Gramm-RudmanHollings approach altogether, replacing it with the Budget Enforcement Act of 1990, 192 which relied mostly on voluntary congressional compliance with deficit targets. In the end, Congress was unable to resist the lure of deficit spending.

Gramm-Rudman-Hollings failed because of the general rule that later legislative enactments are given priority over earlier ones. ${ }^{193}$ But later statutes may not unconstitutionally repeal earlier ones, and the Public Debt Clause may make it unconstitutional for Congress to deviate from a course adopted pursuant to the Public Debt Clause and $\S 5$ of the Fourteenth Amendment. ${ }^{194}$ If Congress explicitly creates a scheme to secure the validity of the public debt, and a subsequent Congress overturns that scheme, such a reversal might constitute a "questioning" of the validity of the debt.

This argument would be strongest for a statute explicitly invoking Sections 4 and 5 and providing that it may be amended only if the modification would not constitute a debt questioning. ${ }^{195}$ A court scrutinizing an amendment to or a repeal of such legislation would then apply an incarnation of either the subjective or the objective test of debt questioning. ${ }^{196}$ As usual, the subjective test would consider whether the change undercut the bond markets' faith in government debt. The alternative objective test would assess whether the change would cause unsustainable debt growth or, using a broader version of the test, would put the government on the path to such unconstitutional growth.

\footnotetext{
${ }^{191}$ For a description of these loopholes, as well as of the failure of Gramm-Rudman-Hollings and the adoption of the Budget Enforcement Act, see Joyce \& Reischauer, supra note 9, at 433-40.

${ }^{192}$ Pub. L. No. 101-508, tit. XIII, 104 Stat. 1388 (codified as amended at 2 U.S.C. §§ 901922 (1996)).

${ }^{193}$ See, e.g., Eisenberg v. Corning, 179 F.2d 275 (D.C. Cir. 1949) (holding that later budgets override inconsistencies with earlier ones).

${ }^{194}$ Section 5 provides that "Congress shall have power to enforce, by appropriate legislation, the provisions of this article."

${ }^{195}$ Even a court that would not have found the abandonment of Gramm-Rudman-Hollings unconstitutional might be wary if Congress had earlier limited a debt-reduction statute's amendability. Congress's power under $\S 5$ to enforce the values of the Public Debt Clause probably extends beyond the courts' power to enforce the Clause's letter. Although Congress has never taken explicit advantage of $\S 5$ in the context of the Public Debt Clause, the Supreme Court has interpreted $\S 5$ broadly in the context of the Equal Protection Clause. In Katzenbach v. Morgan, 384 U.S. 641 (1966), the Court applied a rational-basis test to determine whether congressional action reflected the Fourteenth Amendment's goals. The Court thus upheld the Voting Rights Act of 1965's nullification of an English literacy requirement even though such a requirement was not itself unconstitutional. Similarly, even if abandonment of a debt-reduction scheme would not ordinarily be unconstitutional, the Court might uphold legislation defining such abandonment as a debt questioning since the legislation is rationally related to upholding the goals of the Public Debt Clause.

${ }^{196}$ See supra Subsection II.B.4.
} 
There are two supplemental reasons for viewing the Clause as allowing Congress to tie its own hands with a Gramm-Rudman-Hollings plan. First, the Public Debt Clause is inherently intertemporal, providing that Congress may not renege on an earlier Congress's budgetary commitments. If Congress were to frame a Gramm-Rudman-Hollings scheme as a promise to future purchasers of government securities that it will adhere to a specific budgetary path, or if it incorporated such a promise directly in the bond contract, then deviating from that path might be considered a default on that promise. Second, the only type of legislation that could ensure the validity of the public debt against the will of future Congresses is legislation that ties Congress's hands, so unless $\S 5$ was not meant to apply to $\S 4$, not enforcing hand-tying legislation thwarts the Framers' intent in $\S 5.197$ The problem with this analysis is that it seems too broad, since it would afford all debt legislation quasi-constitutional status. ${ }^{198}$ But this problem vanishes if $\S 4$ and $\S 5$ are read together as allowing Congress to preclude its successors from amending a debt-reduction statute in a way that would constitute a debt questioning.

\section{Entitlements}

Part I's broad construction of what constitutes the "public debt" gives encouragement to those who oppose cuts in Social Security and other entitlement spending. After all, Social Security is a social contract providing for insurance payments to be made in exchange for beneficiaries' earlier contributions. ${ }^{199}$ In essence, with Social Security and Medicare, the United States has accumulated an "implicit pension debt" 200 that the Constitution protects.

Or so the argument goes. But there are reasons--textual, jurisprudential, and practical--that protecting entitlements with the Public Debt Clause begins to stretch the Clause's meaning. First, the social contract that Social Security embodies might not trigger the Clause, because the government has not entered into written agreements with beneficiaries. Second, Part I of this Article left open the question of whether the Clause is

\footnotetext{
${ }^{197}$ Professor Seto similarly notes in the context of the Balanced Budget Amendment that a provision giving Congress enforcement power might allow Congress to override the ordinary rule that subsequent laws supersede prior laws. See Seto, supra note 10, at 1527.

${ }^{198}$ Indeed, such a reading might suggest that Congress may not repeal, or even amend, the debt-limit statute. This would bludgeon Congress into crafting balanced budgets and could lead to unconstitutional debt defaults if Congress failed.

${ }^{199}$ See, e.g., William G. Dauster, Protecting Social Security and Medicare, 33 HARV. J. ON LEGIS. 461 (1996) (describing entitlement programs and urging continued funding).

${ }^{200}$ See Cheikh Kane \& Robert Palacios, The Implicit Pension Debt, Fin. \& Dev., June 1996, at 36 (describing magnitude of unfunded pension obligations in both industrialized and developing countries). The authors note that many countries' debt promises are constitutionally protected. Id. at 36.
} 
implicated when citizens are required to acquire government obligations. Regardless of label, Social Security insurance contributions are a tax. Like the last argument, this one draws a wall, perhaps artificial, between agreements embodied in statutes and those on paper.

Third, the Supreme Court has held, though without considering the Public Debt Clause, that Congress does have the right to cancel Social Security payments. In Flemming $v$. Nestor ${ }^{201}$ the Court ruled constitutional a statute retroactively withdrawing Social Security benefits from aliens deported for Communist Party affiliations. The Court noted that Congress had reserved to itself "[t]he right to alter, amend, or repeal any provision" of the Social Security Act, ${ }^{202}$ and found the beneficiary's absence from the United States a sufficient rationale for the statute to pass muster under the Due Process Clause of the Fifth Amendment. ${ }^{203}$

The fourth, practical reason to be wary of arguments that the Public Debt Clause protects entitlements is that such arguments transform the Clause from a brake against fiscal chaos to an accelerator that could push the economy off the fiscal cliff. ${ }^{204}$ If the government must meet its entitlements promises, then it will need to pay for these promises with high tax rates and drastic reduction in other government services. ${ }^{205}$ However, if Congress waits too long to respond to the impending entitlements crisis, anything might happen in the "generational warfare" that some say would result. ${ }^{206}$ The Supreme Court could overrule Flemming because it failed to consider the Public Debt Clause, ${ }^{207}$ or seize on the Flemming Court's

\footnotetext{
201363 U.S. 603 (1960).

${ }^{202}$ This reservation remains in force. See 42 U.S.C. § 1304 (1996).

203363 U.S. at $611-12$.

${ }^{204}$ This practical concern may help to explain the Supreme Court's disposition in Perry v. United States, 294 U.S. 330 (1935). See supra note 69 and accompanying text. Once the government has accumulated debts that it cannot afford to pay, it may make ex post financial sense to relieve the government of its obligations. Because the Public Debt Clause achieves its purposes by tying Congress's hands ex ante, such a rationale is constitutionally insufficient. But it is understandable that the courts might subvert the Framers' intent, especially given the uncertainty of the government's duty not to renege on entitlement obligations, if enforcing those obligations would be economically disastrous.

${ }^{205}$ Of course, if it became clear in the near future that Congress will not be able to renege on its entitlement obligations, Congress might prospectively reform the system by replacing the pay-as-you-go approach with a fully funded, actuarially sound alternative. See James Tobin, The Future of Social Security: One Economist's Perspective, in SOCIAL SECURITY: BeyOND THE RHETORIC OF CRISIS 41 (Theodore R. Marmor \& Jerry L. Mashaw eds., 1988) (suggesting system linking contributions and benefits). Or, Congress might, as Charles Tiefer predicts, budgetize entitlements entirely by subjecting them to the rigors of the appropriations process. See Tiefer, supra note 122, at 459.

${ }^{206}$ See, e.g., John A Cutter, Tsongas Warns Against 'Generational Warfare’, ST. PETERSBURG Times, Mar. 20, 1994, at 7A.

${ }^{207}$ The Court also could overrule Flemming as incorrectly construing the Due Process Clause. Charles Reich bitterly critiqued Flemming in his ultimately vindicated analysis of “new property." See Charles A. Reich, The New Property, 73 Yale L.J. 733, 768-71 (1964).
} 
comment that its holding does not mean that "Congress may exercise its power to modify the statutory scheme free of all constitutional restraint." Id. at 611. And if Congress were to place entitlement obligations on the full faith and credit of the United States and issue written agreements promising to honor them, the Flemming Court's analysis would crumble and all bets would be off on the applicability of the Public Debt Clause to entitlements.

\section{Justiciability of the Public Debt Clause}

To demonstrate that the federal courts would have jurisdiction over claims filed by debt-holders under the Public Debt Clause, this Part surveys the sovereign immunity, standing, political questions, and ripeness doctrines, as well as separation-of-powers considerations that overlap these areas. Under one view of justiciability, this separate inquiry ought not be required. William Fletcher has argued in the context of standing that the justiciability question is on the merits. ${ }^{208}$ Courts, according to Fletcher, should grant standing to anyone in whom the relevant constitutional or statutory provision sued upon grants legal rights. Similar analyses are possible for other prerequisites to jurisdiction; ${ }^{209}$ for example, a case would be ripe when a legal injury occurred under a particular provision's definition of injury. Under these formulations, this Article's justiciability analysis is done, because the Article conceptualizes the Public Debt Clause as investing legal rights against the United States in debt-holders. Thus, in this view, the Clause overrides sovereign immunity, grants standing, does not delegate a political question to a co-equal branch, creates ripe cases whenever the debt has been questioned, and provides a check on the legislative branch.

The Supreme Court has not embraced this mode of analysis. For example, in Lujan v. Defenders of Wildlife, ${ }^{210}$ the Court held that the Endangered Species Act's grant of citizen standing exceeded the bounds of the Article III judicial power. In nullifying an explicit congressional vesting of a legal right, the Court perpetuated its "injury in fact" jurisprudence. ${ }^{211}$ This test stands in direct opposition to Fletcher's approach, which assesses legal injuries instead of reading a limit to adjudicable harms into Article III. Thus, this Article must conduct an independent analysis of the current state

\footnotetext{
But the Court has so far followed Flemming, holding in 1986 that the Social Security Act created no contractual or property rights. See Bowen v. Public Agencies Opposed To Social Security Entrapment, 477 U.S. 41, 55 (1986).

${ }^{208}$ William A. Fletcher, The Structure of Standing, 98 YALE L.J. 221 (1988).

${ }^{209}$ See, e.g., Akhil Amar, Of Sovereignty and Federalism, 96 YALE L.J. 1425, 1427 (1987) (arguing that “governments have neither 'sovereignty' nor 'immunity' to violate the Constitution”).

210504 U.S. 555 (1992).

${ }^{211}$ See id. at 562-63 (citing Sierra Club v. Morton, 405 U.S. 727, 734-35 (1992).
} 
of justiciability law to determine whether there is any remedy to those governmental practices that the Article brands unconstitutional.

This Part argues that the Supreme Court's jurisprudence does not sap the Public Debt Clause of its relevance. This discussion inevitably veers from the Clause's core, but its conclusions underscore that the private rights protected by the Clause provide a means to enforcing public values. Justiciability doctrines may well endanger many constitutional challenges to the Congress's administration of fiscal policy, ${ }^{212}$ but the Public Debt Clause's protection of debt-holders provides an anchor on which jurisdiction rests comfortably. Although Part III is motivated by the concern that financial mismanagement may impair the general welfare, it is not this diffuse interest but rather the specific financial injury potentially suffered by debt-holders that leads to its conclusions. The Public Debt Clause paves the road to judicial enforcement by conferring rights in a class of individuals whose financial interests are aligned with the social interest of sound financial management that motivates this Article.

\section{A. Sovereign Immunity}

Waivers of sovereign immunity are strictly construed, ${ }^{213}$ but Congress's grants of waivers would cover an action by debt-holders. First, the Tucker Act ${ }^{214}$ granted the sovereign's clear permission to be sued for money damages on an express contract. Indeed, in Perry v. United States, ${ }^{215}$ the Supreme Court held that the Claims Court would have had jurisdiction were the petitioner's calculations of damages correct, but that it could not take jurisdiction over claims for nominal damages. ${ }^{216}$ Therefore, if the government were to repudiate a bond debt, or another debt founded on an express contract, a debt-holder could sue the United States for damages. Second, the United States has consented to suits for relief for other than money damages, as long as the suit is nominally filed against an agency or an official. ${ }^{217}$ A debt-holder could therefore file for declaratory judgment ${ }^{218}$

\footnotetext{
${ }^{212}$ See, e.g., National Treasury Employees Union v. United States, 65 U.S.L.W. 2052 (D.D.C. July 3, 1996) (denying standing in challenge to Line Item Veto Act); Crosthwait, supra note 10 (arguing that Balanced Budget Amendment would be nonjusticiable); Ondrea D. Riley, Comment, Annual Federal Deficit Spending: Sending the Judiciary to the Rescue, 34 SANTA ClaRA L. REV. 577, 594-601 (1994) (assessing standing barriers to challenges of debt accumulation, without considering Public Debt Clause).

${ }^{213}$ See, e.g., Library of Congress v. Shaw, 478 U.S. 310, 318 (1986) (requiring courts to "construe waivers strictly in favor of the sovereign").

${ }^{214}$ Act of March 3, 1887, 24 Stat. 505 (codified as amended at 28 U.S.C. §§ 1346(a)(2), 1491(a)(1) (1996)).

215294 U.S. 330 (1935).

${ }^{216} I d$. at 355.

${ }^{217}$ See 5 U.S.C. $\S 702$ (1996).

${ }^{218}$ See 28 U.S.C. §§ 2201 (1996).
} 
against the Treasury. A taxpayer might, for example, seek a declaration that the federal debt-limit statute or other statute constituting a "debt questioning" is unconstitutional, without violating the United States's sovereign immunity.

The more difficult question is whether the United States would have sovereign immunity if Congress passed a statute withdrawing its consent to suit. In the context of the Fifth Amendment's Just Compensation Clause, the Court has stated that "it is the Constitution that dictates the remedy for interference with property rights amounting to a taking" and thus waives sovereign immunity. ${ }^{219}$ The Court could apply similar reasoning to the Public Debt Clause, or could read the Clause in tandem with the Just Compensation Clause to require compensation for debt repudiations. Indeed, the Perry Court suggested that there might be some limit on Congress's power to make an end-run around the United States's duty to fulfill its credit obligations. $^{220}$ This suggestion recognizes that a key justification of sovereign immunity--"that there can be no legal right as against the authority that makes the law on which the right depends"221--does not apply to constitutional provisions in general and to the Public Debt Clause in particular, since the Clause's purpose is to bind Congress to its earlier commitments. However, in the only case to consider whether Congress may withdraw its consent to suit in a case arising under the Clause, the Court of Claims held that sovereign immunity did protect such a withdrawal. ${ }^{222}$

\footnotetext{
${ }^{219}$ First English Evangelical Lutheran Church v. County of Los Angeles, 482 U.S. 304, 316 n.9 (1987).

${ }^{220}$ See Perry, 294 U.S. at 353 ("The Congress as the instrumentality of sovereignty is endowed with certain powers to be exerted on behalf of the people in the manner and with the effect the Constitution ordains. The Congress cannot invoke the sovereign power of the people to override their will as thus declared.”). Later language makes the import of this statement unclear. See id. at 354 ("While the Congress is under no duty to provide remedies through the courts, the contractual obligation still exists and, despite infirmities of procedure, remains binding upon the conscience of the sovereign.”)

${ }^{221}$ Kawananakoa v. Polyblank, 205 U.S. 349, 353 (1907) (Holmes, J.).

${ }^{222}$ Gold Bondholders Protective Council, Inc. v. United States, 676 F.2d 643 (Ct. Cl. 1982). The case was a delayed Gold Clause action concerning a 1918 bond. After Perry v. United States, 294 U.S. 330 (1935), the Congress had withdrawn its consent to be sued in cases arising under the gold clause provisions of U.S. securities. See 31 U.S.C. § 773b (1983). The court noted, "In an unbroken line of decisions, it has been held that Congress may withdraw its consent to sue the Government at any time," and interpreted dicta in Perry as implying that the Public Debt Clause did not affect this principle. 676 F.2d at 646. But cf. Fitzpatrick v. Bitzer, 427 U.S. 445 (1976) (holding that Fourteenth Amendment overrides sovereign immunity of states under Eleventh Amendment); analogously, the courts could hold that the Fourteenth Amendment's Public Debt Clause overrides the federal government's sovereign immunity.
} 


\section{B. Standing}

Although the Supreme Court's approach to standing is at best confused, ${ }^{223}$ debt-holders almost certainly have the concrete interest in relevant aspects of government fiscal management that the general public lacks. In Allen v. Wright, ${ }^{224}$ Justice O'Connor noted that "application of the constitutional standing requirement [cannot be] a mechanical exercise," but stated that the injury alleged must be "distinct and palpable," "traceable to the challenged action," and "not 'abstract' or 'conjectural' or 'hypothetical."” Repudiation of debts creates a direct and substantial injury, so a challenge to such repudiation would clear these Allen hurdles. Moreover, even restrictive standing decisions have required only that the plaintiff "personally has suffered some actual or threatened injury."225 Therefore, the possibility of injury from, for example, the federal debt-limit statute would be sufficient to allow debt-holders standing to sue on the theory that a debt has been questioned.

A counterargument would equate bondholder standing with taxpayer standing. The government obtains revenue both by borrowing and taxation, so, the argument concludes, bondholders should not have standing where taxpayers would lack it. This argument misses a critical distinction between bondholders and taxpayers: Bondholders, in addition perhaps to the satisfaction of helping fund government programs that may benefit them, have a right to a return on the money they provide. Bondholders would have no greater right than taxpayers to challenge the situation in Allen, in which parents of black school children were concerned that the IRS granting of tax-exempt status to racially discriminatory schools would adversely affect their children's ability to receive an education. Bondholders would have standing, however, to challenge any policy that threatened to burden them with a financial loss, just as taxpayers have standing to attack the constitutionality of tax laws imposing burdens on them. Like such taxpayers, bondholders may well be concerned less about their financial well-being than about the state of constitutional law and government financial management, but public-spiritedness has never deprived a plaintiff with a concrete interest in a case's outcome of standing.

\footnotetext{
${ }^{223}$ Compare Flast v. Cohen, 393 U.S. 83 (1968) (allowing taxpayer standing to challenge of government spending in Establishment Clause case), with Valley Forge Christian College v. Americans United for Separation of Church and State, Inc., 454 U.S. 464 (1982) (denying standing in similar case).

224468 U.S. 737, 751 (1984).

${ }^{225}$ Valley Forge, 454 U.S. at 472 (quoting Gladstone, Realtors v. Village of Bellwood, 441 U.S. 91, 99 (1979)) (emphasis added).
} 


\section{Political Questions}

The political question prong of justiciability bars adjudication of constitutional questions where there is "a textually demonstrable constitutional commitment of the issue to a coordinate political department; or a lack of judicially discoverable and manageable standards for resolving it ...."226 A requirement that "Congress shall ensure the validity of the public debt" might be a delegation of the constitutional issue to Congress, but the passive language of the Public Debt Clause suggests that all the branches of government share the responsibility of ensuring that the debt not be questioned. In addition, although the language of the Public Debt Clause does not eliminate ambiguity, this Article outlines manageable standards for interpreting it. ${ }^{227}$ Certainly the Clause is no less conducive to the adoption of judicial standards than are other provisions of the Fourteenth Amendment to which the courts have added a thick gloss.

\section{Ripeness}

The ripeness doctrine's "basic rationale is to prevent the courts, through avoidance of premature adjudication, from entangling themselves in abstract disagreements . ..."228 Government default is not required to make a disagreement concrete; a debt questioning will do. If a governmental action is found to be a debt questioning under an objective test, then the action has increased the risk of default and thus lowered the value of debt, decreasing the wealth of debt-holders. If a subjective test identifies a debt questioning, then the public is suspicious of a debt's validity and the debt will thus be harder to sell. Either way, a debt questioning inflicts a financial injury. While debtholders may be less concerned about these small injuries than about the possibility of greater injury in the future, the Supreme Court has made clear that immediate, collateral injuries are sufficient to make cases justiciable. ${ }^{229}$

\section{E. Separation of Powers}

Separation-of-powers considerations provide perhaps the most formidable obstacle to the Public Debt Clause. These considerations have independent significance, but have also been folded into the standing and political questions inquiries. For example, in Valley Forge, the Court noted

\footnotetext{
${ }^{226}$ Baker v. Carr, 369 U.S. 186, 217 (1962).

${ }^{227}$ See supra Subsection II.B.4.

${ }^{228}$ Abbott Labs. v. Gardner, 387 U.S. 136, 148 (1967).

${ }^{229}$ See Duke Power Co. v. Carolina Envtl. Study Group, 438 U.S. 59, 81 (1978) (finding ripe suit challenging constitutionality of law limiting liability in event of nuclear accident, because presence of plant would lead to additional, immediate environmental injury).
} 
that a plaintiff may have standing only if a federal court is capable of dispensing relief consistent with the separation of powers. ${ }^{230}$ Also bounded up with separation of powers are "prudential questions" about the wisdom of judicial involvement in a particular area, though this may have lost vitality as an independent doctrine. ${ }^{231}$

Separation-of-powers questions require analysis of whether the courts have the power to order a remedy. Invocation of the Public Debt Clause to invalidate a debt repudiation or the federal debt-limit statute would be an unremarkable exercise of the judicial "duty ... to say what the law is." 232 The application of the Clause to excessive debt accumulation is more troubling. While the courts might issue a mandamus ordering that the deficit be lowered, congressional defiance of such an order would leave the courts without recourse, since rewriting a budget is a quintessentially legislative task that inevitably implicates economic value judgments other than debt reduction. ${ }^{233}$ One solution would be to resolve such cases by granting only money damages; bondholders would be compensated for any decline in the value of their bonds attributable to debt questioning. This approach is workable, but perhaps not a vindication of the Public Debt Clause's values. First, it would exacerbate debt accumulation and thus lead to increased questioning of the remaining portion of the debt. Second, without some form of injunctive relief, it would allow unconstitutional debt accumulation to continue.

Passage of a debt-reduction statute pursuant to $\S 4$ and $\S 5$ of the Fourteenth Amendment ${ }^{234}$ would allay separation-of-powers concerns. First, if Congress were to pass a statute tying its hands, later judicial enforcement of this Congress's will against the will of a future Congress would be less countermajoritarian than garden-variety judicial review. The enforcement would be consistent with the will of a Congress and would reflect the people's desire to create time-inconsistent policies, i.e. policies that produce optimal results ex ante only by precluding later exercise of policymaking discretion. ${ }^{235}$ Second, such a statute could mitigate the difficulty of crafting

\footnotetext{
${ }^{230} 454$ U.S. at 473-74; see also Allen v. Wright, 468 U.S. 737, 752 (1984) (“[T]he law of Art. III standing is built on a single basic idea--the idea of separation of powers.”); Crosthwait, supra note 10, at 1107 n.31. But see Flast v. Cohen, 392 U.S. 83, 99 (1968) (asserting that separation-of-powers is part of political questions inquiry but not standing).

${ }^{231}$ See Crosthwait, supra note 10, at 1089 (arguing that "prudential doctrine is so ill-defined that it is of little use to courts faced with difficult justiciability questions"). But see Nixon v. United States, 506 U.S. 224, 253 (1993) (Souter, J., concurring) (maintaining that political questions doctrine derives "in large part from prudential concerns about the respect we owe the political departments”).

${ }^{232}$ Marbury v. Madison, 5 U.S. (1 Cranch) 137, 177 (1803).

${ }^{233}$ Cf. Lochner v. New York, 198 U.S. 45, 75 (1905) (Holmes, J., dissenting) (arguing that Constitution does not prefer certain economic policies over others).

${ }^{234}$ See supra Subsection III.B.2.

${ }^{235}$ See Finn E. Kydland \& Edward C. Prescott, Rules Rather than Discretion: The
} 
a judicial remedy. By providing a congressionally approved sequestration method, a statute pursuant to $\S 4$ and $\S 5$ would provide a default rule that judges could return to if a later statute were held to breach the Public Debt Clause.

\section{Conclusion}

Although the Public Debt Clause is underdeveloped, it is not a constitutional relic. The language and history of the Clause indicate that it was not merely a prohibition on the repudiation of Civil War bonds. Rather, the Clause was and is a promise that Congress will pay its debts. The Clause applies at least to governmental promises embodied in written agreements with debt-holders, and Congress cannot take any action making it possible that the government will break such promises. As a result, not only would a governmental failure during a budget impasse to make bond or other debt payments be unconstitutional, but the federal debt-limit statute making such an impasse possible is also invalid. Moreover, Congress cannot indulge in unsustainable debt accumulation, and it may be able to ensure the debt's validity by passing debt-reduction legislation that it could not easily repeal. While Congress probably may exercise its reserved right to repudiate its entitlement promises, it might secure those promises by invoking the Public Debt Clause. Suits by debt-holders to enforce the Clause would be justiciable.

Perhaps this interpretation of the Public Debt Clause and its application reflect only the Constitution that was at the time of the Fourteenth Amendment's adoption and the Constitution that might have been in the time since. But to some extent it has also described the Constitution that has been. For although the Supreme Court has not developed the Public Debt Clause, it has strained to find its core elsewhere. The Court has read a version of the Contracts Clause, which applies only to states, into the Fifth Amendment's Due Process Clause, ${ }^{236}$ though the Public Debt Clause seems textually like a better hinge for this holding. And the Court has recognized that statutes may vest recipients of government benefits with property interests that cannot be taken away without

Inconsistency of Optimal Plans, 85 J. POL. ECON. 473 (1977). Professors Kydland and Prescott show that optimal control theory may not apply to dynamic economic systems. In other words, when expectations of future policy influence policy effectiveness, a timeinconsistent policy, i.e. one that prevents policymakers from taking the optimal path at each point in time, may be ex ante optimal. This insight is relevant to debt because a government that can tie its own hands through time-inconsistent policy changes expectations and reaps the lower interest-rate benefits of higher confidence in its bond issues. See also Guillermo A. Calvo, Servicing the Public Debt: The Role of Expectations, 78 Am. Econ. Rev. 647 (1988) (arguing that expectation of debt repudiation makes such repudiation more likely).

${ }^{236}$ See Lynch v. United States, 292 U.S. 571 (1934); LAWrencE TrIBE, AMERICAN CONSTITUTIONAL LAW 613 (2d ed. 1988). 
procedural due process. ${ }^{237}$ These efforts recognize an attractive principle: The Government should not be able to ignore its promises.

This Article asks that the courts use the Public Debt Clause to amplify this principle in the context of congressional budgeting. Although the courts have shown no proclivity to move in this direction, they have not been given the opportunity. Either a suit by bondholders or a decision by Congress to invoke the Clause directly would provide a test case that the courts might use to resuscitate this Clause. And so perhaps this Article has done more than excoriate Congress and the courts for not ensuring the government's fiscal honor; perhaps it has offered a vision of the Fiscal Constitution that might still be.

${ }^{237}$ See Goldberg v. Kelly, 397 U.S. 254 (1970). 